\title{
Review Article \\ Preparative Purification of Recombinant Proteins: Current Status and Future Trends
}

\author{
Mayank Saraswat, Luca Musante, Alessandra Ravidá, Brian Shortt, \\ Barry Byrne, and Harry Holthofer
}

Centre for Bioanalytical Sciences (CBAS), Dublin City University (DCU), Dublin 9, Ireland

Correspondence should be addressed to Harry Holthofer; harry.holthofer@dcu.ie

Received 23 October 2013; Accepted 17 November 2013

Academic Editor: Rita Casadio

Copyright (c) 2013 Mayank Saraswat et al. This is an open access article distributed under the Creative Commons Attribution License, which permits unrestricted use, distribution, and reproduction in any medium, provided the original work is properly cited.

\begin{abstract}
Advances in fermentation technologies have resulted in the production of increased yields of proteins of economic, biopharmaceutical, and medicinal importance. Consequently, there is an absolute requirement for the development of rapid, cost-effective methodologies which facilitate the purification of such products in the absence of contaminants, such as superfluous proteins and endotoxins. Here, we provide a comprehensive overview of a selection of key purification methodologies currently being applied in both academic and industrial settings and discuss how innovative and effective protocols such as aqueous two-phase partitioning, membrane chromatography, and high-performance tangential flow filtration may be applied independently of or in conjunction with more traditional protocols for downstream processing applications.
\end{abstract}

\section{Introduction}

There is an ever-increasing requirement for protein production in industrial and academic settings for a variety of applications. These include exploratory research, drug discovery initiatives, biopharmaceutical production, target validation, and high-throughput screening. Some 200 recombinant proteins-based biopharmaceuticals have gained approval so far for human therapeutic and/or diagnostic use and in excess of 350 are currently in late-stage clinical trials [1]. Notably, pharmaceutical research and manufacturers of America (http://www.phrma.com/) have estimated that its member companies are developing or providing funding for pursuing the development of some 320 biotechnology medicines, with most of these being protein-based. For example, thirty therapeutic complete monoclonal antibodies and three antibody fragments have been approved so far by US FDA as of January 2012 and over 240 are in the developmental stages [1-3]. In addition to biopharmaceuticals, structural genomic initiatives also require milligram $(\mathrm{mg})$ amounts of protein for three-dimensional (3D) structure representations. According to TargetDB statistics as of the first of March 22, 2012, some 295,015 targets have been deposited, out of which
202,005 have been cloned with 128,852 being expressed and 47,784 subsequently purified (http://targetdb-dev.rutgers .edu/TargetDB-dev/stats.html). While currently employed large-scale production strategies yield cell culture/fermentation titres containing up to tens of grams per litre, there is a subsequent need to ensure that all impurities are removed and that sufficient amounts of highly purified protein are obtained for the desired application (http://www.genengnews .com/gen-articles/downstream-bottlenecks-more-than-justperception/4129/). Furthermore, escalating demands for increased protein titres, primarily for economic reasons, have shifted the bottleneck step from production to purification, with downstream processes (inclusive of purification) representing between 45 and $92 \%$ of the total cost of manufacturing a recombinant protein $[4,5]$. Hence, devising an efficient and economical purification strategy is a key challenge and one which is faced by industrial and, to a lesser extent, by academic laboratories. In this review, we provide an overview of the traditional and more recently developed protein purification strategies currently being employed for industrial and academic applications, with particular emphasis on methodologies implemented for the production of recombinant proteins of biopharmaceutical importance. 
TABLE 1: A panel of commonly used affinity tags selected for purification of recombinant fusion proteins and their associated characteristics.

\begin{tabular}{lccc}
\hline Tag & Size [amino acids or kDa] & Ligand or separation method $^{\text {Reference }}$ \\
\hline Polyhistidine & $5-15$ a.a. & IMAC & mAb based \\
HA-tag & 9 a.a. & mAb based & {$[6]$} \\
FLAG & 8 a.a. & Streptavidin & Streptactin \\
Strep tag I & 9 a.a. & mAb based \\
Strep tag II & 8 a.a. & mAb based \\
Softag 1 & 13 a.a. & mAb based \\
Softag 3 & 8 a.a. & mAb based \\
T7-tag & $11-16$ & S-protein \\
c-myc & 10 a.a. & {$[10]$} \\
S-peptide & 15 a.a. & {$[11]$} \\
Polyaspartic acid & $5-16$ a.a. & Ion-exchange or precipitation \\
VSV tag & 11 a.a. & mAb based \\
Calmodulin binding peptide & 26 a.a. & Calmodulin \\
Glutathione S-transferase & $26 \mathrm{kDa}$ & Glutathione \\
Maltose binding domain & $40 \mathrm{kDa}$ & Maltose, amylose \\
PinPoint (Promega) & $13 \mathrm{kDa}$ & Streptavidin/avidin \\
Cellulose binding domain (Novagen) & $27-189$ a.a. & Cellulose \\
Xylanase 10A & 163 a.a. & Cellulose
\end{tabular}

${ }^{a}$ Only one relevant reference is given.

\section{Chromatography Material Functionalities}

2.1. Affinity Chromatography. There are numerous ways in which an affinity-based method may be employed for the purification of recombinant proteins. The most common example of an affinity process is protein-A chromatography, which has been applied for over a decade in industrial and academic settings for the capture and purification of antibodies (immunoglobulins) [23]. In spite of several notable drawbacks associated with the use of this technology, primarily the ability of protein-A to leak into the mobile phase and the high associated costs, it is still widely used as a capture step in large-scale purification of monoclonal antibodies (mAbs), including those of therapeutic use [24]. Recombinant protein-A-bound resins with high binding capacities (e.g., MAbSelect Sure by GE Healthcare) are commercially available and can withstand the harsh sterilising conditions introduced between cycles of industrial downstream processing. What makes protein-A-based applications more lucrative for industrial uses, in spite of their obvious disadvantages, is their ability to indirectly remove viruses (such as SV40, XMuLV, and MMV) from the feed [25]. Moreover, the ability to capture mAbs directly from clarified harvest without any pretreatment and very high selectivity leading to removal of most host cell proteins are two distinct advantages of proteinA chromatography. Another affinity-based strategy which has been utilised for the easy purification of recombinant proteins is the use of fusion tags, namely amino acid sequences which are attached to recombinant proteins and have selective and highaffinities for a chemical or biological ligand which is immobilised on a chromatography column, hence permitting purification of the recombinant protein. Commonly used affinity tags (and their cognate binders) which permit purification of a selection of tagged proteins are outlined in Table 1.

In particular, the histidine (His) tag has been frequently used to facilitate purification of recombinant proteins from bioprocess mixtures [26-30]. This tag is comprised of a sequence of six or more histidine residues which are added to either the $\mathrm{N}$ or $\mathrm{C}$ terminal of the recombinant protein of interest and exhibits a high affinity towards metal ions such as nickel (Ni) and zinc ( $\mathrm{Zn})$. Immobilised metal affinity chromatography (IMAC) uses a matrix which has a metalchelating group available for metal binding, and the remaining coordination sites on the metal bind His residues attached to the recombinant protein, thus enabling its purification via elution with a metal chelator such as imidazole. IMAC is commonly used as a protein purification strategy in academic $[31,32]$ and industrial settings [33]. Furthermore, several therapeutic candidate protein pharmaceuticals purified using IMAC are currently in clinical studies [34-38]. Naturally occurring metal-binding proteins and the presence of histidine and cysteine-rich spots in superfluous proteins compete with tagged protein to bind to the column and interfere with IMAC often resulting in contamination of the final product. However, it is a common initial purification method for HIS tagged recombinant proteins and purities up to $95 \%$ with recovery of $90 \%$ can be achieved in a single step [39]. Moreover, IMAC resin is unaffected by protease activity in the feed unlike many other biological affinity procedures. HIS tagged proteins can be eluted from IMAC by mild elution conditions which would help in recombinant proteins retaining their activity and/or native folding. However, possibility of heavy metal leaching from the column during purification can be of 
concern [40] and testing for it would require additional costs for validation. Finally, the removal of HIS tag would require expensive proteases and additional chromatographic steps needed to purify the target protein would further increase the costs.

Alternative tags (e.g., FLAG, Softag1, and Softag3, Table 1) bind to specific mAbs raised against them (such as ANTIFLAG M1 Agarose Affinity Gel from Sigma) which, in turn, can be used for immunopurification of tagged proteins. However, there is an increased cost associated with the use of $\mathrm{mAbs}$, while harsh chromatography conditions may have a deleterious effect on the ability of the antibody to bind to its cognate antigen over multiple purification cycles. Strep tag II is an octapeptide (WSHPQFEK) which recognises streptavidin and can be eluted from the streptavidin-containing column using biotin analogues. Hence, this tag can be used for purifying proteins expressed in a selection of different host systems [10, 41]. Notably, these tags can be removed via proteolytic cleavage of the linker region between the ligand and analyte, and passing the analyte through the tag-binding column for a second time can yield pure protein free of nonspecific binders and proteases. However, as mentioned above, these proteases are expensive and the use of these tags would increase the cost of downstream processing.

Downstream processing of biopharmaceuticals usually represents the major cost of protein manufacturing, and a single-step isolation of a recombinant protein using an affinity ligand with high selectivity and stability is therefore an ideal strategy [3]. Affinity chromatography has been used for purification of proteins for many years, and recent progress in combinatorial and de-novo ligand design seem very promising [42]. The design of ligands which can be used for purification of target protein(s) can be performed in various ways, including protein structure-based design, functionbased design, and through combinatorial approaches such as bacteriophage display, ribosome display, and systematic evolution of ligands by exponential enrichment (SELEX) [42]. Structure-based design of ligands takes advantage of the known 3D structure of the target protein and identifies a site for ligand binding which has a known active site [43], a surface-solvent exposed area [44] or a site used by a natural ligand to bind [45]. The designed ligand is docked to the protein structure and binding mode, affinity, and molecular parameters are calculated using different algorithm-based software. These parameters can also be estimated experimentally using, for example, Surface Plasmon Resonance (SPR) analytical platforms (e.g., Biacore from GE Healthcare or Octet by ForteBio), which have dedicated software for data analysis, quartz-crystal microbalance (QCM) analysis, or isothermal titration calorimetry. There are reports of successful ligand design approaches in the literature. As an example, a biomimetic dye-ligand designed for L-lactate dehydrogenase (LDH) was used for its purification from a selection of different sources, including bovine heart, chicken liver, pig muscle, and pea seeds [46]. Other examples of successful dye-ligand-based purification approaches have been reported [47-49]. This illustrates the potential and selectivity of using this approach for purification from complex sample matrices.
Function-based design is implemented when the structure of the target protein is unknown. Here, the purification strategy selected for use is based on any functional information available for the target protein. One example is Cibracon blue 3GA, which adopts nucleotide-like conformations and can be used for the purification of nucleotide-binding proteins [50]. Biomimetic compounds mimicking known substrates, inhibitors, or cofactors of target proteins can also be used as affinity ligands. Some of the dye adsorbents for protein purification are commercially available from various companies.

Synthetic peptide or phage/ribosome display libraries have been used to identify peptide ligands which bind to target proteins with high affinities. Based on these approaches, a hexapeptide (FLLVPL) was identified from a synthetic peptide library and used for the purification of human fibrinogen [51], while other high-affinity ligands for target proteins can be identified from phage libraries through a process termed biopanning [52]. For example, Benlysta was approved by FDA, in 2011, for the use in lupus and the antibody was discovered by phage display technology and further developed for commercial use. SELEX was used to identify a deoxyribonucleic acid (DNA) aptamer which was able to purify human L-selectin-immunoglobulin fusion protein expressed in Chinese hamster ovary (CHO) cells [53]. More recently, a small molecule affinity ligand for human growth hormone (hGH) was identified through screening of a combinatorial library which was enriched through a combination of computational and online screening. Using this ligand, hGH was purified from microfiltered Escherichia coli (E. coli) lysate with high levels of recovery (83\%) and purity (80\%) observed [54]. Another important aspect of this study is that small molecule affinity ligands are more advantageous than biomolecule ligands as they can tolerate harsh conditions such as in the routine sterilisation of resins performed in industry and thus function for an increased number of cycles which is of notable economic importance. However it is to be noted that small molecule ligands make for less specificity, leading to copurification of other factors and low productivity of the process, which is a key disadvantage for their routine use. Although affinity chromatography can be a very useful method in terms of selectivity and affinity, it is never used independently for the purification of recombinant proteins, mainly due to the fact that access to suitable ligands is often scarce and endotoxin and glycoform contamination has also to be taken into account.

2.2. Ion-Exchange Chromatography. Ion-exchange chromatography (IEX) still remains one of the most frequently implemented initial steps for protein separation in industry and for most of academia, provided that the target protein is not tagged and not an mAb. There are many reasons for this, such as the fact that proteins are amphoteric molecules and any protein will bind to an ion-exchange resin depending on the $\mathrm{pH}$ of the solution. IEX provides high resolution under mild conditions with high binding capacity. The $\mathrm{pH}$ of the buffer selected for binding and elution affects the charge on weak ion exchangers but not on strong ion exchangers which retain 
their charge over a wide $\mathrm{pH}$ range. Hence, they are usually the resins of choice in commercial bioprocess operations. Pilotscale studies are usually carried out to determine the binding of a target protein to a resin of interest and to determine the effect of different ionic concentrations and $\mathrm{pH}$ before scaling-up. Elution is performed by altering the $\mathrm{pH}$ or ionic strength of the solution and because the reproducibility of the $\mathrm{pH}$ shift is less, a salt gradient is preferred on a large scale. Theoretically, any salt can be used for elution because all of them modulate electrostatic interactions and thusbinding and elution.

The "salting-out" effect of a salt on a protein, its valency, and ion binding to proteins determine the elution properties of a salt, which explains the different elution properties of salts with the same valencies [55]. "Salting-out" can induce higher binding to IEX resin and therefore salts such as sodium chloride $(\mathrm{NaCl})$ which have weak "salting-out" effects on proteins are preferentially selected for elution over high "salting-out" salts such as ammonium sulphate $\left(\mathrm{NH}_{4}\right)_{2} \mathrm{SO}_{4}$. Ion exchange can be robustly used for aggregate removal as shown in studies for the $\mathrm{mAb}$ and other recombinant protein purification [56, 57]. Moreover, the presence of 0.15$0.2 \mathrm{M}$ arginine in the binding buffer was shown to be more effective than salts like citrate and $\mathrm{NaCl}$ in reducing aggregate formation during elution [58]. Even when the resin that binds the target protein is a cation exchange (CEX) resin, an anion-exchange (AEX) resin is often used in tandem for effecting the removal of deoxyribonucleic acid (DNA) and lipopolysaccharide (LPS) impurities from the feed [59]. Usually, IEX and other chromatographic methods require the feed (or loading material) to be free from cells and cellular debris, which introduces an additional centrifugation or filtration which may be costly and/or time consuming.

The removal of low-level impurities structurally related to the product has been a challenge for the bioprocess industry and traditionally this has been facilitated by using shallow linear salt gradients at low column loadings, hence limiting the throughput [60]. Displacement chromatography incorporates an element which displaces the components of loading feed by having a higher affinity for the stationary phase which results in a zone of purified feed components that runs ahead of the displacer. Different types of displacers may also bind to resin-bound protein and enhance the binding, resulting in the displacement of the protein to the displacement zone.

Ion-exchange displacement chromatography has received attention for being a powerful technique, facilitating the purification of biomolecules, and one of the reasons for this relates to its superior resolving power in differentiating between related protein variants [60]. Another demonstration of its high resolution is the fact that ion-exchange displacement chromatography can separate proteins having similar retention properties in traditional IEX [61]. In addition, there is a wide variety of choice available for selecting suitable displacers, and these include carbohydrates, their derivatives, proteins, and even low molecular mass displacers like dendrimers, protected amino acids, and antibiotics [62-66]. Furthermore, high-throughput screening can be employed to screen a library of displacer analogues to select the most applicable displacer for purification of target protein present in a mixture of proteins [61]. However removal of displacers from target molecule solutions and their recycling issues, leading to increased costs, are disadvantages of this mode of chromatography. Moreover, because displacers have high affinity for the resins, their removal from column during regeneration presents a challenge and extreme $\mathrm{pH}$ or very high percentage of organic solvent may be necessary. This reduces throughput and increases costs. Another interesting study describes an alternative mode of IEX, namely, backflush ion exchange chromatography which was implemented for purifying recombinant aldehyde dehydrogenases (ALD4p and ALD6p) and a methyltransferase (Bud23p) from $E$. coli extracts in a single step. In this method, sample was loaded onto a $\mathrm{Q}$ sepharose Fast Flow column in the opposite direction to which it is eluted, and the $\mathrm{pH}$ of the sample was kept higher than the $\mathrm{pI}$ value of the target protein [67]. Keeping the pH high kept impurities held back to be eluted in high salt concentrations and protein of interest was eluted as a single peak with little or no protein eluting with it. However, the binding conditions for this technique has to be empirically determined for every protein in question as other target proteins in the study did not bind at the $\mathrm{pH}$ which was used for Bud23p.

\subsection{Hydrophobic Interaction Chromatography. Hydrophobic} interaction chromatography (HIC) is a popular method for protein purification, and, similar to other chromatographic techniques, the ability to integrate mathematical modelling of the process and to calculate the hydrophobicity of the target protein simplifies the design of purification processes. Proteins bind to HIC hydrophobic ligands on resins based on their hydrophobicity, which is also indicative of the separation conditions such as retention times of a given protein and therefore performance of HIC [68]. Protein hydrophobicity is determined by the amino acids that constitute the proteins, with high concentrations of salt (e.g., ammonium sulphate) exposing the surface hydrophobic patches and thus enabling the binding of proteins to the HIC column. Subsequent elution is performed by a decreasing gradient of salts. This makes HIC a method of choice just after IEX-based elution or ammonium sulphate precipitation during a purification scheme, as eluate and precipitate have high salt concentrations which favours binding to HIC resins. Theoretical methods to determine a target protein's hydrophobicity so as to predict the retention of protein on a given HIC resin have been described previously [69]. Furthermore, amino acids (glycine and arginine), polyols (ethylene glycol and glycerol), and sugars (sucrose) have also been shown to modulate binding and elution of proteins to HIC resins [70]. The use of "salting-out" salts results in low protein recovery and the application of stronger conditions present the risk of denaturing protein during the purification. Solvent modulators can be used to overcome this problem. For example, arginine, up to a certain critical concentration, has been shown to weaken the protein binding to HIC resins [71] and has been implemented for the elution of interleukin6 (IL-6) and monoclonal antibodies [58]. In some cases, 
the effect of arginine is more dramatic, for example, for activin [71]. To elaborate, as a sticky protein, activin was not eluted from the HIC resin by low citrate concentration and even by $20 \%(\mathrm{v} / \mathrm{v})$ ethanol. However, $0.5 \mathrm{M}$ arginine resulted in $60 \%$ recovery of this protein, with a sharp elution peak of activin observed [71]. In summary, HIC can be used for separation of recombinant proteins, homologous proteins, and antibodies and since the separation of protein on HIC operates on a different principle to IEX and other purification methods, it can be applied in conjunction with these methodologies to purify proteins from very complex biological mixtures [72]. Moreover HIC operates on high-salt binding conditions and IEX elutes in them; it can be used as a next step after IEX without the requirement of a buffer exchange.

2.4. Mixed-Mode Chromatography. Mixed-mode or multimodal chromatography has also recently being developed and applied to a wide range of purification processes [73]. The lack of requirement for high ionic strength for solute binding to mixed-mode resins, facile elution and the unique selectivity offered by these resins is enhancing their popularity among the industrial community for protein purification schemes. Principles, characteristics and design of ligands for mixed mode chromatography have been discussed previously [74]. Mixed-mode resin selectivity results from electrostatic interactions and hydrophobic interactions as well as hydrogen bonding, depending on case-to-case basis. Hydroxyapatite (HA) chromatography is a traditional example of mixed-mode chromatography in which protein can bind to resin via either HA-phosphoryl (cation-exchange) or HA-calcium residues (metal affinity). Small basic proteins usually bind to the HA by phosphoryl-cation exchange and acidic proteins interacting predominantly by calcium affinity. However, large proteins can bind using both mechanisms [75]. HA is available in either microcrystalline form or as spherical particles. Microcrystalline HA is not mechanically stable, which limits its use in batch mode only, while spherical particles can be used over multiple cycles [76].

A popular HA used for recombinant protein purification (e.g., antibodies) is ceramic HA (CHT by Bio-Rad Laboratories). HA chromatography is also particularly useful for removing aggregates of proteins which may be present alongside the target protein in a crude mixture. Furthermore, the presence of poly-ethylene glycol (PEG) in the binding buffer enhances the retention of protein on the HA column, and this is proportional to the size of the target protein. This results in aggregates of the protein being retained on the column for longer than their monomeric counterparts, thus facilitating the removal of aggregates [75]. A clear separation of leached protein-A from the previous chromatography step, DNA, endotoxins, viruses, host cell proteins, and aggregates from monomeric immunoglobulin $\mathrm{G}$ ( $\mathrm{IgG}$ ) has been reported using CHT [77], which further demonstrates its efficacy. In a further application of CHT, mAb specific for Japanese encephalitis virus was purified in two steps using HA chromatography and membrane filtration without using the usual protein-A step [78]. In this study, 90.2\% purity along with $90 \%$ recovery was achieved and antigen binding activity was preserved in the product. The running time was reduced to one-third of the conventional method which would reduce operation cost in a process. However, mechanical instability, low reusability, and high costs are some of disadvantages of CHT chromatography.

Other mixed-mode resins have also been developed and a number of companies have brought their own mixed-mode resins to the market. Some of the commercially available multimodal media and their characteristics are outlined in Table 2. In one study evaluating mixed-mode resins, to remove aggregates from antibody preparations, Capto adhere (GE healthcare, Piscataway, NJ, USA) and Benzylamine (BA, prepared according to [79]) were able to remove aggregates from $20.5 \%$ to $2.6 \%$ and $2.4 \%$, respectively, for a load of $50 \mathrm{mg} / \mathrm{mL}$ of resin [80]. In the same study, the ability to remove aggregate from antibody preparations by resins employing electrostatic interactions (Q Sepharose FF) and hydrophobic interaction (Phenyl Sepharose $6 \mathrm{FF}$ ) was found to be lower compared to mixed-mode resins (Capto adhere and $\mathrm{BA}$ ) employing both types of interactions. In another study, Capto adhere, for loading up to $100 \mathrm{mg} / \mathrm{mL}$ of resin, was able to reduce aggregates from $10.5 \%$ to $2.3 \%$ while traditional anion-exchange resins showed a reduction from $12.8 \%$ to $11.4 \%$ [81]. However IEX is a good technique to reduce aggregates but mixed-mode chromatography demonstrably performs better than IEX in aggregate removal and should be tested in larger studies with more varied type of culture mediums. As more and more resins become available with unique selectivity and higher binding capacities, this will likely result in mixed-mode chromatography becoming more frequently used in future academic and industrial protein purification applications.

2.5. Size Exclusion Chromatography. Size exclusion chromatography (SEC), also referred to as gel permeation chromatography or molecular sieving, separates molecules based on their hydrodynamic volume and has been implemented for several decades for protein purification applications. Here, retention times for larger molecules are shorter than for smaller analytes and hence this property permits efficient separation, provided that assay conditions are optimised. The same principle can be taken advantage of if trying to desalt or exchange the buffer of a protein solution for another buffer. Resolution between differently sized molecules is a function of resin pore size, bed height, flow rate, mobile phase composition, and sample size. SEC stationary phases typically have a low resolution in separating molecules of different size. Therefore, the careful selection of a suitable stationary phase is an absolute necessity, especially, considering the size of the target molecule and associated superfluous contaminants. The retention time of a protein and its subsequent resolution are affected by the composition of the mobile phase. Proteins interact with stationary phase molecules by electrostatic and hydrophobic interactions which delay their retention times, resulting in a loss of resolution or increased peak volume which might not be desirable [82]. A decrease in mobile phase $\mathrm{pH}$ lowers the ionisation of acidic proteins. Furthermore, low 
TABLE 2: Selected commercially available mix-mode media.

\begin{tabular}{|c|c|c|c|c|}
\hline Media & Supplier & Type & Ligand & pH stability \\
\hline $\begin{array}{l}\text { CHT ceramic } \\
\text { hydroxyapatite }\end{array}$ & $\begin{array}{l}\text { Bio-Rad } \\
\text { laboratories }\end{array}$ & Ion exchange, metal chelation & {$\left[\mathrm{Ca}_{5}\left[\mathrm{PO}_{4}\right]_{3} \mathrm{OH}\right]_{2}$} & $\begin{array}{l}\text { Operating pH: } 5.5-14 \\
\text { Can be cleaned with 1-2 M NaOH }\end{array}$ \\
\hline CHT Fluorapatite & $\begin{array}{c}\text { Bio-Rad } \\
\text { laboratories }\end{array}$ & Ion exchange, metal chelation & {$\left[\mathrm{Ca}_{10}\left[\mathrm{PO}_{4}\right]_{6} \mathrm{~F}\right]_{2}$} & $\begin{array}{l}\text { Operating pH: } 5-14 \\
\text { Can be cleaned with 1-2 M NaOH }\end{array}$ \\
\hline MEP & Pall life sciences & $\begin{array}{l}\text { Hydrophobic binding near } \\
\text { neutral } \mathrm{pH} \text {, elution by } \mathrm{pH} \\
\text { reduction }\end{array}$ & $\begin{array}{l}\text { 4-Mercapto ethyl } \\
\text { pyridine }\end{array}$ & $\begin{array}{l}\text { Working pH: 2-12 } \\
\text { Cleaning pH: 2-14 }\end{array}$ \\
\hline HEA & Pall life sciences & $\begin{array}{l}\text { Hydrophobic binding near } \\
\text { neutral } \mathrm{pH} \text {, elution by } \mathrm{pH} \\
\text { reduction }\end{array}$ & Hexylamino & $\begin{array}{l}\text { Working pH: } 2-12 \\
\text { Cleaning pH: } 1-14\end{array}$ \\
\hline PPA & Pall life sciences & $\begin{array}{l}\text { Hydrophobic binding near } \\
\text { neutral } \mathrm{pH} \text {, elution by } \mathrm{pH} \\
\text { reduction }\end{array}$ & Phenylpropylamino & $\begin{array}{l}\text { Working pH: 2-12 } \\
\text { Cleaning pH: 1-14 }\end{array}$ \\
\hline MBI & Pall life sciences & $\begin{array}{l}\text { Hydrophobic binding at acidic } \\
\mathrm{pH} \text {, elution by raising the } \mathrm{pH}\end{array}$ & $\begin{array}{l}\text { 2-Mercapto-5- } \\
\text { benzimidazole sulfonic } \\
\text { acid }\end{array}$ & - \\
\hline Capto MMC & GE Healthcare & Multimodal cation exchange & $\begin{array}{l}\text { 2-Benzamido-4- } \\
\text { mercaptobutanoic } \\
\text { acid }\end{array}$ & $\begin{array}{l}\text { Long term: } 2-12 \\
\text { Short term: } 2-14\end{array}$ \\
\hline Capto adhere & GE Healthcare & $\begin{array}{l}\text { Multimodal strong anion } \\
\text { exchange }\end{array}$ & $\begin{array}{l}\text { N-benzyl-N-methyl } \\
\text { ethanolamine }\end{array}$ & $\begin{array}{l}\text { Long term: } 3-12 \\
\text { Short term: } 2-14\end{array}$ \\
\hline
\end{tabular}

ionisation reduces the stationary phase-protein interaction of acidic proteins. The $\mathrm{pH}$ of the mobile phase can be selected taking into consideration the nature of the target protein to be isolated and contaminants, so as to increase the retention time of the contaminant(s) and reduce that for the target protein, or vice-versa. Another factor influencing the retention time is ionic strength. High phosphate concentrations and moderate $\mathrm{NaCl}$ concentrations suppress the electrostatic interaction of proteins with the stationary phase [83]. However, high concentrations of, for example, ammonium sulphate may enhance the protein adsorption to the stationary phase through hydrophobic interactions which increases retention. The inclusion of organic solvents such as acetonitrile in the mobile phase can reduce these interactions [84] but may also denature the target protein and result in the underestimation of aggregate content. However, the use of $0.2 \mathrm{M}$ arginine was shown to reduce protein-stationary phase interactions, increasing recovery of a mouse $\mathrm{mAb}$ by 2.39-fold and improving the accuracy of aggregate content analysis when recombinant human activin, interleukin-6, basic fibroblast growth factor, mouse $\mathrm{mAb}$ (purified from myeloma cell conditioned media), and interferon- $\gamma$ were used as a mixture of model proteins [85].

Proteomic approaches for selecting a purification method based on physicochemical properties, and optimisation of operating conditions using mathematical modelling have been described previously [86]. Because of its poor resolution and excellent desalting properties SEC is mostly used as a polishing step when the volume has been reduced and the removal of aggregates and a change of solution are necessary. Moreover, samples volumes needed for SEC are very small therefore a concentrating step is needed increasing the costs of the process. To achieve good separation in SEC, long columns are needed and low flow rates are necessary due to back pressure constraints and both of these factors reduce the productivity. These above-mentioned issues are key disadvantages of SEC in industrial settings. High-performance tangential flow filtration can also perform concentration and buffer exchange in a single step (Section 4) and this methodology appears to be gradually replacing SEC in industrial downstream processing. However, SEC is widely used as an analytic technique to estimate and monitor percentage of aggregates in a given sample.

\section{Continuous Chromatography}

Typically in traditional column chromatography, for example, protein-A chromatography, the column is loaded up to $90 \%$ of $1 \%$ breakthrough capacity which leads to insufficient utilisation of the column's capacity [87]. Moreover, while the end of the column remains unsaturated, the entrance to the column is saturated resulting in excess buffer consumption used in washing and elution stages [88]. These factors limit throughput at preparative scale. Notwithstanding these limitations, some of these factors can be overcome in a continuous operation where continuous product injection and product withdrawal are performed. There are multiple types of continuous chromatography models and operations. For example, multicolumn counter current solvent gradient purification is a process capable of providing high yield and purity of products $[89,90]$. It is particularly useful for resolving variants of proteins with an intermediate product being accompanied by weakly and strongly adsorbing variants such as $\mathrm{mAb}$ variants $[91,92]$. It has, however, been successfully 
applied to purification of mAbs directly from cell culture supernatant as well [93].

The major advantages of the counter current-simulated moving bed technique are reduced solvent consumption, increased productivity, and more concentrated product which collectively contribute to cost reduction in any given process [94]. These continuous operations have been recently used successfully for purification of recombinant streptokinase [95], mAb [87, 88], single-chain antibody fragment [31], and capture of IgG on a cation-exchange column, [96]. Of notable interest is the observation that each of these studies reported either significant cost savings and/or better productivity and performance compared to batch mode chromatography. In recent years, continuous chromatography has been employed in a variety of chromatographic systems and applications including protein-A affinity $[87,88]$, cationexchange [96], immobilized metal ion affinity chromatography [31], and hydrophobic interaction chromatography [95].

One major attraction of using counter current chromatography is predictable scale-up of the process from test tube analytical scale to pilot/process scale. For example, a scale-up from $5.4 \mathrm{~mL}$ to $4.6 \mathrm{~L}$ using the calculations done on test tube scale (calculation of distribution ratios) have been reported by Sutherland et al. [97]. The retention time for binary separations (benzyl alcohol $\{4.5 \mathrm{~min}\}$ and p-cresol $\{6.5 \mathrm{~min}\}$ ) was similar however; resolution fell down from 1.54 to 1.01 [97]. However, the separation of the binary mixture was not significantly affected. Continuous separation in a protein production plant is very attractive in terms of cost as well. It was shown in a study that variable costs for operations of continuous systems are approximately $4.0 \mathrm{M}$ $\$ /$ year lower than that of batch separation systems [98]. This is because of the lower operating costs (resin efficiency, less solvent consumption, etc.) of the continuous plant.

\section{Field-Assisted and Electrophoretic Separation Methods}

As mentioned previously, downstream processes account for the majority of the cost during the production of a biopharmaceutical preparation and, hence, there is a constant need for the development of novel, improved, and more costeffective methods for protein separation. Electric, acoustic and magnetic fields can be used alone or in conjunction with established separation methods (e.g., membrane-based methods) for the separation of proteins. With reference to the latter, bio-macromolecules such as proteins and cells exhibit ferromagnetism, paramagnetism, and diamagnetism [99]. Although magnetic separation of cells is out of the scope of this review, fermentation media may be frequently contaminated with cells which need to be separated from the protein of interest. Magnetic particles bearing affinity ligands for cells may be added to the medium and separated by a magnet, a methodology which has routinely been used for the isolation of microbial cells from culture medium [99]. Affinity-based magnetic methods similar to that seen for the separation of cells have also been used for separating proteins, DNA and ribonucleic acid (RNA) from nutrient media, fermentation broths, tissue extracts and biological fluids [99]. A schematic representation of the process involved in the magnetic separation of macromolecules or cells is shown in Figure 1.

Another field-assisted technique, namely, free-flow electrophoresis (FFE), may be implemented for the purification of cells and proteins from different sources, including human sample matrices (e.g., urine and serum). FFE has some advantages over chromatographic methods such as continuous sample injection and the ability to separate crude extracts containing cells and subcell particles. On the other hand, some disadvantages for scale-up are also evident, such as the need for specialised instrumentation and the requirement for the optimisation of multiple parameters for complex sample analysis. FFE was used for IgG purification by human plasma fractionation in a single step and $79 \%$ recovery with clinical grade purity (IVIG grade) was achieved [100]. In the same study, when process was adjusted to become two-phase process, $93 \%$ recovery and $98.8 \%$ purity were achieved and the process could be scaled up to 100 times with $93 \%$ yield of IgG. In another study, the complete purification of cytochrome $\mathrm{C}$ and myoglobin from a binary mixture was achieved by a combination of FFE and a micromodule fraction separator [101]. Recombinant human growth hormone (rhGH) was purified (98\%, with $90 \%$ yield) from culture medium of $\mathrm{CHO}$ cells in a single step using gradiflow preparative electrophoresis and a $50 \mathrm{kDa}$ separation membrane, which demonstrates the power of electrophoresis in separating proteins [102]. Gradiflow preparative electrophoresis is easily scalable [103] and can be used for the purification of recombinant proteins at large volumes. In a separate study, FFE was compared with multiple chromatographic and filtration steps for permitting the purification of mutant recombinant tumour necrosis factor- $\alpha$ (TNF- $\alpha)$ and the yields and purity were comparable for both procedures [104]. Finally, preparative electrophoresis is a powerful technique for the purification of protein and although it has been utilised to a lesser extent during largescale purification of proteins at industrial and academic levels, it warrants further attention due to its high resolution and ability to perform continuous separations in a costeffective manner by replacing multiple chromatographic steps. However, issues in scale-up and complex method setup have to be taken into account, and, theoretically, continuous chromatography would fare better in an industrial process.

\section{Membrane-Based Systems}

Membranes are interfaces acting as a barrier between liquidliquid and liquid-vapour phase contacting two sides of an interface. Membranes are popular in the biotechnology industry for protein purification/concentration, depending on the size and/or charge of the target proteins. In addition, they offer key advantages pertinent to cost and ease of scalingup over chromatographic methods. Currently, membranebased systems are routinely used in industry and academia for downstream processing of recombinant proteins [105107]. The highest interest among the use of membranes has been on the pressure-driven processes, such as ultrafiltration 


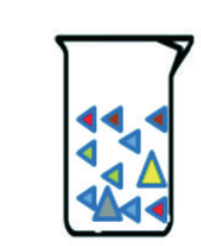

Complex mixture of macromolecules



Purified protein

FIgURE 1: Magnetic separation of macromolecules from a complex sample matrix.

(UF), microfiltration, virus filtration, and nanofiltration. Ultrafiltration membranes are usually $1-20 \mathrm{~nm}$ in size and their protein retention is very high. They are mainly used for protein concentration and buffer exchange and appear to be used in preference to SEC on an industrial scale, [108]. The permeability of a membrane is determined by pore size distribution, porosity, thickness, and solvent properties. Any charge present on membranes will alter the flow and, consequently, protein transport across the membrane [109]. The hydrophobicity of the membrane also plays a key role and reduces the flow and process permeability due to protein adsorption [110]. Polyethersulfone (PES) membranes are more hydrophobic compared to their cellulose-based equivalents. Membrane fouling also has a similar effect on process permeability and is a limitation for the use of UF. Many modules like hollow fibre, spiral-wound, flat-sheet cassettes, and tubular modules have been developed for UF. They provide separation of retentate and filtrate streams, mechanical support, and easy access for cleaning and replacement, in addition to enhanced mass transfer properties [111].

Although UF is routinely used in industries for protein concentration and buffer exchange, protein separation by single step UF is still a challenge. However, there are several examples of protein purification from complex matrices using UF in the literature. Purification of recombinant collagen from corn extracts was achieved with up to $99 \%$ purity using UF membranes [112]. The permeate flux was improved with higher transmembrane pressure and high crossflow rates $(.25 \mathrm{~m} / \mathrm{s})$. In another study, the purification of lysozyme from chicken egg white and the associated effect of different parameters, such as $\mathrm{pH}$, system hydrodynamics, feed concentration, and transmembrane pressure on permeate flux, have been studied using hollow-fibre PES membranes [113]. Here, it was observed that system hydrodynamics did not affect the purity or lysozyme transmission through the membrane, whereas higher retention was observed at higher crossflow velocities due to increased permeate flux. Three-or four-stage cascade UF was employed for lysozyme purification from chicken egg white and in four-stage cascade $97 \%$ purity and $71 \%$ recovery were achieved using PES and polysulfone membranes in flat-sheet tangential flow and hollow fiber mode [114]. Negligible membrane fouling was found in this system and internal flow rates affected product recovery and not purity. UF membranes can also be made of polyacrylonitrile, cellulose, and cellulose acetate and ceramic, among other materials. Traditional UF membranes mostly differentiate between proteins based on their respective sizes, and a tenfold difference is usually necessary for effective separation. However, charged membranes have shown more promise in permitting the separation of proteins like myoglobin, bovine serum albumin (BSA) and recombinant fragment antigen binding (Fab) fragment and a full-length antibody $[115,116]$.

Ultrafiltration under the effect of an electric field (electroultrafiltration, EUF) is also being analysed for protein purification and, in one study, it increased flux permeate by $25-$ $50 \%$ in a protein solution of $1-5 \mathrm{~g} / \mathrm{L}$ compared to the UF performed in the absence of any electric field [117]. EUF has also been used to reduce membrane fouling and applying a critical voltage eliminates particle deposition at the membrane and restores the flux $[118,119]$. It was identified in one study that the most suitable conditions resulting in the highest average filtration flux can be reached by applying higher voltage, shorter pulse intervals, and longer pulse durations [120]. However, electrolysis occurring at the membrane and resulting local $\mathrm{pH}$ changes might result in inactivation or denaturation of target molecule. The application of ultrasonic energy at high power to a liquid produces acoustic streaming and shear forces by cavitations in a liquid, which leads to reduced membrane fouling and increased permeate flux [121]. Application of higher frequency ultrasound leads to greater 


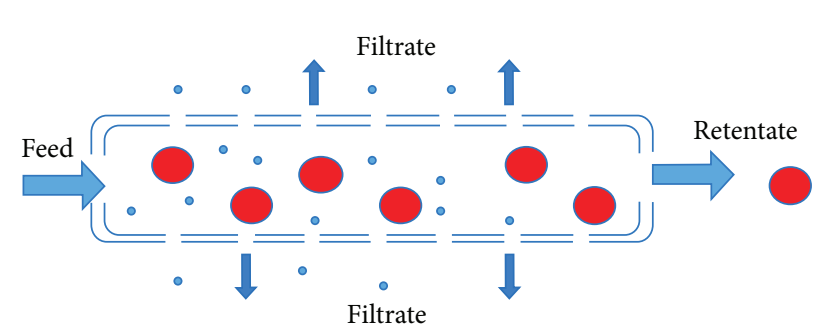

(a)

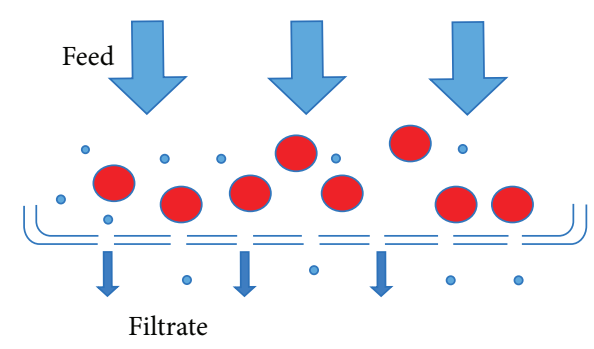

(b)

Figure 2: Tangential flow (a) and dead end filtration (b) methodologies.

acoustic streaming flow rates compared to lower frequencies for the constant power intensity [122]. In some studies it was found that electric and ultrasonic fields had synergistic effects when both fields were applied simultaneously [123, 124]. Electric field assisted separation for lysozyme and bovine serum albumin has been reported [125]. Recently, using the same technique, purification of soy peptides from a complex mixture was achieved [126]. However, the modelling of retention under the effect of electric field is complex and this might delay the development of this technique for recombinant protein purification.

Another emerging technology in membrane separation processes is high-performance tangential flow filtration (HPTFF). A schematic representation of dead-end filtration and tangential flow filtration is shown in Figure 2. Conventional tangential flow filtration can separate molecules differing in size up to 10 -fold or higher, but HPTFF can distinguish between molecules differing in size by up to 3 -fold by optimisation of buffer and fluid dynamics and through the use of selectively charged membranes. HPTFF takes into account both the size and charge of a molecule and can perform protein concentration, purification, and buffer exchange in a single operation, hence reducing the cost of downstream processing [127]. At their isoelectric points, proteins have a net neutral charge and, therefore, have no ionic layer and a low effective volume which results in a high sieving coefficient and high passage of protein through the membrane pores. This effect is more pronounced at low ionic strength concentrations, and high ionic strength reduces the effective volume which in turn changes the sieving coefficient. Hence, careful optimisation of buffer $\mathrm{pH}$, ionic strength and, the use of charged membranes result in a process which is highly selective for product protein retention and allows impurities to pass through [128]. HPTFF has been used to separate protein monomers from oligomers, protein variants differing in only one amino acid, and a Fab fragment from a similarly sized impurity which demonstrates the high selectivity which can be obtained $[129,130]$. More recently, this technique, in combination with anion-exchange membrane chromatography, has been used to purify recombinant penicillin acylase from bacterial cultures with relatively high purity 19 units/mg and recovery (72\%) [107]. Clarification of the culture was simultaneously achieved making the process economical requiring less steps.
An alternative membrane-based separation process, membrane chromatography, uses microfiltration or larger pore size membranes which have ligands immobilised to the inner pore surface which results in the highly selective separation of proteins. Ion-exchange, affinity reversed phase, and hydrophobic interaction membranes have been developed and Pall (New York, USA) Mustang Q and S membranes are examples of anion- and cation-exchange membranes, respectively. Flat sheet, stacked sheet, and pleated modules are also available for membrane chromatography applications. Membrane chromatography has been applied in both flow through and bind-and-elute industrial applications [111]. For flow through applications, process parameters are optimised such that impurities are bound and retained allowing the product of interest to flow through. For example, in one study leached protein- $\mathrm{A}$ and aggregates of $\mathrm{mAb}$ bound reversibly to the poylvinylidene membranes while $\mathrm{mAb}$ flowed through separating it from impurities [131]. This application was based on hydrophobic interactions and membrane was regenerated by lowering the salt concentration releasing the aggregates and protein-A. This methodology has also been used in bindand-elute applications for DNA, RNA, and viruses [132, 133]. In terms of dynamic binding capacity and economics, membrane chromatography fares well with beads-based media for larger solutes (such as mAbs) but cannot compete for smaller solutes (smaller proteins). However, developments in membrane structure and device design should compensate for this in future applications [111].

\section{Phase Partitioning}

Out of the all the downstream processing steps, the selective purification steps represent $70 \%$ of the total costs and are dominated by chromatography-based methodologies such as those outlined above [134]. Notably, the increasing upstream titres required to satisfy the demands for higher protein yields place considerable economic and physical pressure on these systems. This means that there is an absolute requirement for the development and implementation of alternative steps which either purify the proteins independently or reduce the burden on the normally applied purification step (e.g., chromatography) by partial purification. One of these systems is liquid-liquid extraction, for example, aqueous two-phase partitioning. Aqueous two-phase systems are formed by mixing 


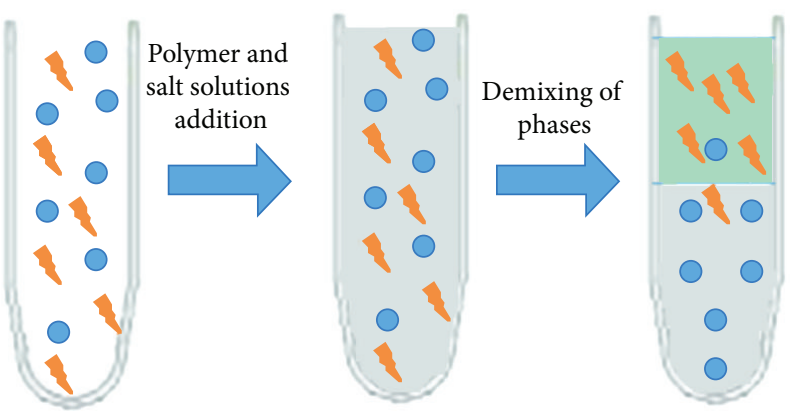

FIGURE 3: Separation of constituents through the implementation of aqueous two-phase partitioning.

of two aqueous solutions of structurally different components above a certain critical concentration [135]. These different components can be two different polymers or a polymer and a salt (Figure 3 ). In downstream processing of proteins, product phase consists of water, and most polymers have stabilising effects on protein structure [136]. Therefore, these techniques are compatible with protein-producing systems and offer the advantage of combining concentration and purification in a single step with easy scale-up.

Aqueous two-phase extraction (APTE) has also been used to purify cells, viral particles, and plasmid DNA [137139]. Properties of biomolecules, like hydrophobicity, surface charge, size, and system composition, affect the partitioning of the molecule in any two-phase system. This implies that partitioning of a protein in aqueous two-phase systems can be manipulated by altering the polymer mass, $\mathrm{pH}$, ionic strength, and concentration of the phase component or through the addition of affinity ligands. This gives flexibility to design and allows for the optimisation of a system which targets the protein to one phase and most of the impurities to another. High-throughput screening can be used to determine the partitioning coefficient and effect of different phase component parameters like mass of polymer, $\mathrm{pH}$, and ionic strength [140].

Factorial designs and central composite designs have also been used to screen and optimise the partitioning of a biomolecule and establish the effect of different parameters on partitioning [141, 142]. Traditionally polyethylene glycol (PEG)/dextran and PEG/salt (e.g., potassium phosphate) systems have been selected for use, but temperature-separating polymers, such as ethylene oxide-propylene oxide (EOPO), and $\mathrm{pH}$-sensitive polymers for example, polydiallylamineethanoate-dimethyl sulfoxide (PAEDS), have also been reported [143-145]. After the biomolecule has been targeted to the polymer phase, temperature- or $\mathrm{pH}$-sensitive polymers can be recovered by altering the $\mathrm{pH}$ or temperature to precipitate the polymer for further use, while the target biomolecule remains in the solution. Yields in separation by the EOPO system have been reported to be enhanced by the addition of nonionic detergents [146] or through the addition of a hydrophobic tag (tryptophan, tyrosine, or hydrophobin I) to the target protein [147]. Many reports discussing the APTE-based extraction of mAbs, insulin-like growth factor (IGF), hGH, and insulin have been reported in the literature [148].

Another system called three-phase portioning (TPP) has also been reported. Here, one phase is an organic liquid phase like t-butanol and another phase is a salt (e.g., ammonium sulphate), with an interphase spontaneously formed. TPP is particularly useful for the extraction of proteins from cell extracts, as cellular debris tends to partition to the organic phase, with nucleic acid partitioning to the interphase. Many important biomolecules such as green fluorescent protein (GFP), xylanase, and antigenic proteins have been recovered by using this methodology [149-151], demonstrating its feasibility to be integrated into a purification process. Recently, catalase was purified from sweet potato tubers in a single step using TPP with 14.1 fold purification [152]. However, recovery of organic solvent for multiple uses and validation of its successful removal from the final product are important considerations. APTE is becoming the method of choice increasingly in downstream operations of biopharmaceuticals because of the ease of scale-up, continuous operation, biocompatibility, low toxicity of polymers and chemicals used, and possibility of process integration [153155]. Moreover, it can perform clarification, concentration and partial purification in one step but comparing it with other processes in terms of purity alone it does not fare well. Its ability to be integrated into any industrial process along with the above-mentioned examples makes this technique suitable for any purification process [156]. In case of TPP, the use of organic solvent might affect activity of some proteins and usability of TPP has to be determined on a case-per-case basis.

\section{Endotoxin and Virus Removal}

Endotoxin and pathogen removal from therapeutics of biological nature is of paramount importance primarily because of their human uses. Gram-negative bacteria are widely used for production of recombinant proteins for therapeutic uses which entails methods to reduce endotoxin levels to those permitted by regulatory authorities. The development of costeffective and efficient methods for endotoxin removal is an ongoing challenge for the biopharmaceutical industry. Endotoxins are highly stable molecules resisting extreme temperature and $\mathrm{pH}$ which makes it challenging to just neutralise them using harsh conditions without the loss of activity of target recombinant proteins. Based on the unique molecular properties of endotoxins, many methods like affinity resins, membrane adsorbers, ion-exchange and hydrophobic interaction chromatography, two-phase extractions and ultrafiltration have been developed for endotoxin removal with varying degrees of success [157]. Most methods designed for endotoxin removal work on a case-to-case basis depending on the properties of target proteins, and a single broadly applicable method is hard to find. For example, positively charged proteins such as urokinase can be decontaminated using anion-exchange chromatography due to the net negative charge of endotoxin [158], but, negatively charged proteins will pose the problem of product loss because they will bind to the column with endotoxins as well. 
Likewise, small proteins can be ultrafiltered to remove large endotoxin aggregates but with large target proteins like fulllength antibodies, this approach would not work due to overlapping in size of the product and impurity. Another major problem would be interaction of endotoxin with proteins which might affect their solution behavior and, consequently, the strategy to be implemented for effecting their removal [159]. Alcohols can be used to remove LPS from LPS-protein complexes although safer, non-flammable alternatives such as alkanediols have also been proposed and found to remove LPS in combination with ion-exchange chromatography [160]. More recently, various factors affecting the removal of endotoxin from protein solutions using anion-exchange chromatography were evaluated [161]. It was reported that $\mathrm{pH}$ could be kept sufficiently high to prevent the conferring of a positive charge to the protein to facilitate dissociation of the endotoxin bound to the protein. Thereafter, resin volume can be increased to prevent saturation of resin with endotoxin and some conductivity can be applied to maintain low interaction between endotoxin and protein. Keeping all these factors regulated, an endotoxin content of $0.5 \mathrm{EU} / \mu \mathrm{g}$ and $80 \%$ product recovery were achieved. However, the success of this method may have something to do with the molecular properties of model proteins used in the study, although these factors can be considered while designing endotoxin removal methods for any target protein. Affinity resins including immobilised L-histidine, poly-L-lysine, poly ( $\gamma$-methyl L-glutamate) and polymyxin $\mathrm{B}$ have also been traditionally used to remove endotoxins from protein solutions [162-165]. A new affinity ligand for endotoxin removal has been recently synthesised and was found to be better than histidine immobilised silica in removing endotoxins from BSA solutions [166]. Another interesting approach was implemented in which recombinant monoclonal antibody bound to an affinity resin was washed with $0.5 \mathrm{M}$ arginine which resulted in a dramatic reduction of protein-bound endotoxin content and a final endotoxin content of $0.2 \mathrm{EU} / \mathrm{mg}$ of target protein with $95 \%$ product recovery was achieved [167]. This is an interesting method as arginine is a nontoxic amino acid and can be readily removed from protein solutions by washing the column if the protein is column-bound or by filtration if it is a protein solution. Another method for endotoxin removal which is very promising is aqueous two-phase micellar system (ATPMS). In ATPMS, an aqueous surfactant under appropriate solution conditions spontaneously separates into two phases, micelle-rich and micelle-poor phase [168]. A careful optimisation of the conditions can result in partitioning of target protein into one phase while the endotoxin partitions in another phase. Recently, one study described that green fluorescent protein (GFP) produced in E. coli was found to partition preferentially into micelle-poor phase, while LPS partitioned into the micelle-rich phase [169]. Previously, one study concluded that for decontamination of various proteins such as, troponin-I, myoglobin, and creatine kinase, a twophase extraction using Triton X-114 was noted to provide improved performance relative to affinity adsorption [170]. A separate study noted that a polymyxin B resin was found to be to equivalent to APTMS in removing LPS from DNA preparations [171]. Therefore, when referencing the literature, one does not find a single method which is broadly applicable to remove endotoxin from any target protein and a case-tocase method development and validation are a recommended strategy to implement.

The strategies used for virus removals from recombinant proteins including antibodies are low $\mathrm{pH}$ inactivation, detergent treatment, membrane filtration, protein-A chromatography, and AEX [172, 173]. One important consideration in protein-A and AEX based methods is the robustness of the virus removal over recycling of the resin. Protein-A chromatography removes viruses from antibody solutions by allowing them to flow through the column while retaining antibodies [25]. The robustness of the clearance is dependent on the lifetime of the column and can be reflected in step yield and antibody breakthrough (concentration of antibody passing in effluent) [174]. In the case of AEX, the robustness can be reflected in band spreading, an increase in back pressure, or impurities in process fluid [175]. These factors should be checked to determine the robustness of the process in virus removals. Since, AEX shows DNA binding, it is superior in removing viruses from the feed. In virus filtration, membrane fouling over time can reduce the effectiveness of virus clearance probably owing to reduced pore size [176]. Emerging technologies for virus removal are smartly designed ion-exchange or ligand-coupled membranes which are disposable [177]. One clear advantage of this method is that one can design very tight-binding membranes because the binding does not need to be reversible. These membranes allow very high flow rate and therefore short processing time and thus are cost effective and validation becomes easy because of them being disposable.

\section{Future Trends and Conclusion}

The purification of expressed protein is usually the bottleneck in the cost of protein production and this has put immense pressure on the need to develop novel purification methods and make improvements to existing strategies. Here, we have discussed the rapid development of affinity chromatography and how combinatorial approaches for ligand discovery are revolutionising this field. These ligands can be engineered to be made stable at the wide $\mathrm{pH}$ and temperature ranges used in cleaning and sterilisation of affinity columns, thus simplifying their use over multiple purification cycles. This ultimately reduces the cost of the purification process while also increasing the product yield. Due to its high selectivity, affinity chromatography is usually the preferred first step in purification of recombinant proteins on small or larger scales. The use of protein-A chromatography for antibody purification, notwithstanding its high costs, is an example. It should be noted that proteinaceous ligands for use in affinity chromatography applications have their limitations as they cannot withstand the harsh cleaning conditions introduced between purification cycle batches, which limits their reuse and increase associated costs. An improved protein-A ligand engineered to withstand cleaning with $0.5 \mathrm{M} \mathrm{NaOH}$ has been reported, and there is notable interest in its use in 
industrial downstream processing for purifying recombinant antibodies.

Separately, the use of combinatorial chemistry and phagedisplay technologies is generating a large repertoire of ligands specific for virtually any protein. It is likely that these ligands will be increasingly used in future applications for large-scale recombinant protein purification. Companies like SomaLogic (CO, USA) and VersaMatrix (Denmark) have launched custom ligand discovery services based on these approaches, and future applications comprised of reduced numbers of purification steps look increasingly promising. Furthermore, existing chromatographic processes are constantly improving and processes such as back-flush ion exchange and displacement chromatography are continuously in development. Once these and other methodologies are fully developed, this will lead to significant improvements in selective purification of target proteins.

The limiting factor for large-scale use of displacement chromatography is the lack of selective displacers. However, many of these have recently become commercially available, suggesting that this technology will become increasingly more popular for industrial purification processes. Many companies have developed mixed-mode stationary phases which offer unique selectivity and higher capacity than existing media. These media for IEX, HIC those of and mixed-mode chromatography are also more robust and can tolerate the sanitisation conditions which consequently allow multiple reuse. In case of processes where affinity ligands are not costeffective and traditional ion exchangers are unsuitable, mixed-mode media can provide an alternative which reduces the number of process steps and provides unique selectivity. An increasing number of companies are launching mixed-mode media into the market which are robust for in-place cleaning and provide unique selectivity for binding to either the target protein or impurities which reduce the cost of the process by lowering the number of process steps, which is a key economic consideration. Trend will be towards continuous processes for all types of chromtographies as this required less buffer consumption and results in high productivity compared to batch processes.

Large bead hydrogel-based technologies such as insideout ligand attachment (IOLA), developed by LigoChem (NY, USA) are also very promising. IOLA promotes ligand attachment to the inner surface of the beads which are chosen based on target protein size, and larger impurities including viruses and other proteins cannot enter the beads and, thus, are washed out. In addition, HPTFF and membrane chromatography are rapidly emerging systems for protein purification and provide alternatives to traditional chromatographic systems. Although currently membrane chromatography cannot compete with traditional bead-based chromatography for binding of small solutes, newer developments should address this drawback. Membrane chromatography is already popular for viral removal, and this technique has immense further potential. For example, membranes with protein-A mimetics or other affinity ligands for target proteins can be envisioned in future developments. We also postulate that, by making improvements to the flow characteristics of membranes, this will result in enhanced performance and lead to higher protein purification titres.

We have discussed how aqueous two-phase partitioning is very selective, user friendly, and rapid. Notwithstanding their high costs, associated polymers are nontoxic, which is an important benefit for processes seeking approval for the production of therapeutics intended for human use. However, it should be noted that an important drawback of phase partitioning separation methods for industrial uses is the slow rate of phase demixing. However, field-assisted demixing and electroextraction appear to overcome this limitation. ATPE is also attractive because it can concentrate the target protein with a high degree of separation during the initial stages of the purification, which ultimately reduces the burden from subsequent chromatography-based steps. It should also be acknowledged that a limitation of ATPE which requires further studies is the scarcity of knowledge pertinent to the mechanism and partitioning behaviour of different proteins in various ATPE systems. This makes mathematical simulation of ATPE process difficult as it is not possible to accurately predict the partitioning of proteins.

Endotoxin removal is an important consideration in any pharmaceutical of biological origin produced in bacteria. Although detergents are effective in reducing endotoxin content during chromatography, on a larger scale, they would be very costly. Alkanediol and alcohol are alternatives and alkanediols should be preferentially selected owing to safety. One interesting and working approach would be arginine washing coupled to affinity chromatography which has been shown to work well. APTMS is a new and very promising technique which can be implemented in early stages of downstream processing to remove the majority of endotoxins. However, process parameters for Triton X-114 are not well defined and future studies are needed. Moreover, new chemicals which break endotoxin-protein complexes without affecting protein binding to chromatographic resins or endotoxin binding to affinity resin could also be a viable strategy. While, in case of virus removal, membranes with ion-exchange or affinity functionality seem to be the future trend with associated advantage of nonreversible binding and ease of validation.

Finally, it should be concluded that the efficient and costeffective purification of proteins from a complex biological mixture is an important challenge for industrialists and academics alike, and currently none of the aforementioned methods can be used independently for efficient protein purification. However, mathematical modelling (simulation) and high-throughput screening of operational conditions in downstream processing have become integral parts of these processes and will play an even greater role in future applications for the design of product-specific downstream strategies. Furthermore, as more innovative technologies are developed and demonstrated to be effective for purification applications (e.g., single-use or disposable purification platforms), it appears likely that these will be applied more frequently in biopharmaceutical processes for lowering costs, reducing analytical times, and increasing yields of target proteins. 


\section{Conflict of Interests}

The authors declare no conflict of interests, financial or otherwise.

\section{Acknowledgments}

This study was supported by funding from the Science Foundation Ireland (SFI), Health Research Board of Ireland (HRB), and the Office of the Vice President of Research (OVPR), Dublin City University, Ireland.

\section{References}

[1] G. Walsh, "Biopharmaceutical benchmarks 2010," Nature Biotechnology, vol. 28, no. 9, pp. 917-924, 2010.

[2] W. R. Strohl, "Therapeutic monoclonal antibodies: past, present, and future," in Therapeutic Monoclonal Antibodies: From Bench to Clinic, pp. 1-50, John Wiley \& Sons, New York, NY, USA, 2009.

[3] P. A. Marichal-Gallardo and M. M. Alvarez, "State-of-the-art in downstream processing of monoclonal antibodies: process trends in design and validation," Biotechnology Progress, vol. 28, no. 4, pp. 899-916, 2012.

[4] A. J. J. Straathof, "The proportion of downstream costs in fermentative production processes," in Comprehensive Biotechnology, M.-Y. Murray, Ed., vol. 2, pp. 811-814, Academic Press, Burlington, Mass, USA, 2nd edition, 2011.

[5] C. R. Lowe, "Combinatorial approaches to affinity chromatography," Current Opinion in Chemical Biology, vol. 5, no. 3, pp. 248-256, 2001.

[6] S. Chatterjee, J. Schoepe, S. Lohmer, and D. Schomburg, "High level expression and single-step purification of hexahistidinetagged L-2-hydroxyisocaproate dehydrogenase making use of a versatile expression vector set," Protein Expression and Purification, vol. 39, no. 2, pp. 137-143, 2005.

[7] D. S. Hage, "Affinity chromatography: a review of clinical applications," Clinical Chemistry, vol. 45, no. 5, pp. 593-615, 1999.

[8] A. Einhauer and A. Jungbauer, “The FLAGÜ peptide, a versatile fusion tag for the purification of recombinant proteins," Journal of Biochemical and Biophysical Methods, vol. 49, no. 1-3, pp. 455465, 2001.

[9] T. G. M. Schmidt and A. Skerra, "The random peptide libraryassisted engineering of a C-terminal affinity peptide, useful for the detection and purification of a functional Ig Fv fragment," Protein Engineering, vol. 6, no. 1, pp. 109-122, 1993.

[10] C.-P. Witte, L. D. Noël, J. Gielbert, J. E. Parker, and T. Romeis, "Rapid one-step protein purification from plant material using the eight-amino acid StrepII epitope," Plant Molecular Biology, vol. 55, no. 1, pp. 135-147, 2004.

[11] S. J. Duellman, N. E. Thompson, and R. R. Burgess, "An epitope tag derived from human transcription factor IIB that reacts with a polyol-responsive monoclonal antibody," Protein Expression and Purification, vol. 35, no. 1, pp. 147-155, 2004.

[12] N. E. Thompson, T. M. Arthur, and R. R. Burgess, "Development of an epitope tag for the gentle purification of proteins by immunoaffinity chromatography: application to epitope-tagged green fluorescent protein," Analytical Biochemistry, vol. 323, no. 2, pp. 171-179, 2003.
[13] D. K. Chatterjee and D. Esposito, "Enhanced soluble protein expression using two new fusion tags," Protein Expression and Purification, vol. 46, no. 1, pp. 122-129, 2006.

[14] K. Terpe, "Overview of tag protein fusions: from molecular and biochemical fundamentals to commercial systems," Applied Microbiology and Biotechnology, vol. 60, no. 5, pp. 523-533, 2003.

[15] R. T. Raines, M. McCormick, T. R. Van Oosbree, and R. C. Mierendorf, "[23] The S.tag fusion system for protein purification," Methods in Enzymology, pp. 362-376, 2000.

[16] K. Stubenrauch, A. Bachmann, R. Rudolph, and H. Lilie, "Purification of a viral coat protein by an engineered polyionic sequence," Journal of Chromatography B, vol. 737, no. 1-2, pp. 7784, 2000.

[17] E. A. Green, C. Botting, H. M. Webb, T. R. Hirst, and R. E. Randall, "Construction, purification and immumogenicity of antigen-antibody-LTB complexes," Vaccine, vol. 14, no. 10, pp. 949-958, 1996

[18] D. L. Wyborski, J. C. Bauer, C.-F. Zheng, K. Felts, and P. Vaillancourt, "An Escherichia coli expression vector that allows recovery of proteins with native $\mathrm{N}$-termini from purified calmodulin-binding peptide fusions," Protein Expression and Purification, vol. 16, no. 1, pp. 1-10, 1999.

[19] C. Scheich, V. Sievert, and K. Büssow, "An automated method for high-throughput protein purification applied to a comparison of His-tag and GST-tag affinity chromatography," BMC Biotechnology, vol. 3, article 12, 2003.

[20] R. Eliseev, A. Alexandrov, and T. Gunter, "High-yield expression and purification of 18 form of Bax as an MBP-fusion protein," Protein Expression and Purification, vol. 35, no. 2, pp. 206-209, 2004.

[21] L. Brown, J. L. Yin, and B. Hambly, "Direct cloning of polymerase chain reaction products into the pinpoint Xal-T vector protein expression system," Electrophoresis, vol. 19, no. 5, pp. 860-866, 1998.

[22] M. Kavoosi, J. Meijer, E. Kwan, A. L. Creagh, D. G. Kilburn, and C. A. Haynes, "Inexpensive one-step purification of polypeptides expressed in Escherichia coli as fusions with the family 9 carbohydrate-binding module of xylanase 10A from $T$. maritima," Journal of Chromatography B, vol. 807, no. 1, pp. 8794, 2004.

[23] H. F. Liu, J. Ma, C. Winter, and R. Bayer, "Recovery and purification process development for monoclonal antibody production," $m A b s$, vol. 2, no. 5, pp. 480-499, 2010.

[24] W. Jiskoot, J. J. C. C. Van Hertrooij, J. W. T. M. K. Gebbinck, T. Van der Velden-de Groot, D. J. A. Crommelin, and E. C. Beuvery, "Two-step purification of a murine monoclonal antibody intended for therapeutic application in man. optimisation of purification conditions and scaling up," Journal of Immunological Methods, vol. 124, no. 1, pp. 143-156, 1989.

[25] S. Lute, L. Norling, M. Hanson et al., "Robustness of virus removal by protein A chromatography is independent of media lifetime," Journal of Chromatography A, vol. 1205, no. 1-2, pp. 1725, 2008.

[26] M. V. C. Nguyen, L. Zhang, S. Lhomme et al., "Recombinant Nox 4 cytosolic domain produced by a cell or cell-free base systems exhibits constitutive diaphorase activity," Biochemical and Biophysical Research Communications, vol. 419, no. 3, pp. 453-458, 2012.

[27] H. Song, E. Park, Y.-H. Shin, H. Kim, and D. Na, "Effect of polyhistidine-tagging site on the stability of recombinant 
alginate lyase from Streptomyces sp. ALG-5," Journal of Pharmaceutical Investigation, vol. 42, no. 1, pp. 15-19, 2012.

[28] B. Cass, P. L. Pham, A. Kamen, and Y. Durocher, "Purification of recombinant proteins from mammalian cell culture using a generic double-affinity chromatography scheme," Protein Expression and Purification, vol. 40, no. 1, pp. 77-85, 2005.

[29] A. Badar, S. DeFreitas, J. M. McDonnell et al., "Recombinant complement receptor 2 radiolabeled with $\left[{ }^{99 \mathrm{~m}} \mathrm{Tc}(\mathrm{CO})_{3}\right]^{+}$: a potential new radiopharmaceutical for imaging activated complement," PLoS One, vol. 6, no. 4, Article ID e18275, 2011.

[30] S. D. Cline, S. Saleem, and D. A. Daines, "Regulation of the vapBC-1 toxin-antitoxin locus in nontypeable haemophilus influenzae," PLoS One, vol. 7, no. 3, Article ID e32199, 2012.

[31] C. A. M. Cristancho, F. David, E. Franco-Lara, and A. SeidelMorgenstern, "Discontinuous and continuous purification of single-chain antibody fragments using immobilized metal ion affinity chromatography," Journal of Biotechnology, vol. 163, no. 2, pp. 233-242, 2013.

[32] A. Seidler, "Introduction of a histidine tail at the N-terminus of a secretory protein expressed in Escherichia coli," Protein Engineering, vol. 7, no. 10, pp. 1277-1280, 1994.

[33] C. Fiore, V. Trézéguet, P. Roux et al., "Purification of histidinetagged mitochondrial ADP/ATP carrier: influence of the conformational states of the C-terminal region," Protein Expression and Purification, vol. 19, no. 1, pp. 57-65, 2000.

[34] R. L. Shimp Jr., L. B. Martin, Y. Zhang et al., "Production and characterization of clinical grade Escherichia coli derived Plasmodium falciparum $42 \mathrm{kDa}$ merozoite surface protein 1 (MSP142) in the absence of an affinity tag," Protein Expression and Purification, vol. 50, no. 1, pp. 58-67, 2006.

[35] C. A. Darko, E. Angov, W. E. Collins et al., "The clinicalgrade 42-kilodalton fragment of merozoite surface protein 1 of Plasmodium falciparum strain FVO expressed in Escherichia coli protects Aotus nancymai against challenge with homologous erythrocytic-stage parasites," Infection and Immunity, vol. 73, no. 1, pp. 287-297, 2005.

[36] C. F. Ockenhouse, E. Angov, K. E. Kester et al., "Phase I safety and immunogenicity trial of FMP1/AS02A, a Plasmodium falciparum MSP-1 asexual blood stage vaccine," Vaccine, vol. 24, no. 15, pp. 3009-3017, 2006.

[37] E. Angov, B. M. Aufiero, A. M. Turgeon et al., "Development and pre-clinical analysis of a Plasmodium falciparum Merozoite surface protein-142 malaria vaccine," Molecular and Biochemical Parasitology, vol. 128, no. 2, pp. 195-204, 2003.

[38] J. A. Stoute, J. Gombe, M. R. Withers et al., "Phase 1 randomized double-blind safety and immunogenicity trial of Plasmodium falciparum malaria merozoite surface protein FMP1 vaccine, adjuvanted with AS02A, in adults in western Kenya," Vaccine, vol. 25, no. 1, pp. 176-184, 2007.

[39] J. A. Bornhorst and J. J. Falke, "[16] Purification of proteins using polyhistidine affinity tags," Methods in Enzymology, vol. 326, pp. 245-254, 2000.

[40] J. Crowe, H. Döbeli, R. Gentz, E. Hochuli, D. Stüber, and K. Henco, "6xHis-Ni-NTA chromatography as a superior technique in recombinant protein expression/purification," Methods in Molecular Biology, vol. 31, pp. 371-387, 1994.

[41] T. G. M. Schmidt and A. Skerra, "The Strep-tag system for one-step purification and high-affinity detection or capturing of proteins," Nature Protocols, vol. 2, no. 6, pp. 1528-1535, 2007.

[42] P.-Å. Nygren, "Affinity ligands from biological combinatorial libraries," in Protein Purification: Principles, High Resolution
Methods, and Applications, pp. 269-278, John Wiley \& Sons, 3rd edition, 2011.

[43] R. Li, V. Dowd, D. J. Stewart, S. J. Burton, and C. R. Lowe, "Design, synthesis, and application of a protein A Mimetic," Nature Biotechnology, vol. 16, no. 2, pp. 190-195, 1998.

[44] S. F. Teng, K. Sproule, A. Husain, and C. R. Lowe, "Affinity chromatography on immobilized 'biomimetic' ligands: synthesis, immobilization and chromatographic assessment of an immunoglobulin G-binding ligand," Journal of Chromatography $B$, vol. 740, no. 1, pp. 1-15, 2000.

[45] U. D. Palanisamy, D. J. Winzor, and C. R. Lowe, "Synthesis and evaluation of affinity adsorbents for glycoproteins: an artificial lectin," Journal of Chromatography B, vol. 746, no. 2, pp. 265281, 2000.

[46] N. E. Labrou, E. Eliopoulos, and Y. D. Clonis, "Molecular modeling for the design of a biomimetic chimeric ligand. application to the purification of bovine heart L-lactate dehydrogenase," Biotechnol Bioeng, vol. 63, no. 3, pp. 322-332, 1999.

[47] D. Gondim, L. Lima, M. de Souza et al., "Dye ligand epoxide chitosan/alginate: a potential new stationary phase for human IgG purification," Adsorption Science \& Technology, vol. 30, no. 8-9, pp. 701-712, 2012.

[48] N. Kaya, D. A. Uygun, S. Akgöl, and A. Denizli, "Purification of alcohol dehydrogenase from saccharomyces cerevisiae using magnetic dye-ligand affinity nanostructures," Applied Biochemistry and Biotechnology, vol. 169, no. 7, pp. 2153-2164, 2013.

[49] A. Silva, R. E. F. Boto, C. T. Tomaz, J. A. Queiroz, and P. Almeida, "Rhodamine B as ligand for affinity chromatography: chromatographic studies on derivatized beaded cellulose," Journal of Chromatographic Science, vol. 48, no. 3, pp. 240-244, 2010.

[50] Y. D. Clonis, N. E. Labrou, V. P. Kotsira, C. Mazitsos, S. Melissis, and G. Gogolas, "Biomimetic dyes as affinity chromatography tools in enzyme purification," Journal of Chromatography A, vol. 891, no. 1, pp. 33-44, 2000.

[51] D. B. Kaufman, M. E. Hentsch, G. A. Baumbach et al., "Affinity purification of fibrinogen using a ligand from a peptide library," Biotechnology and Bioengineering, vol. 77, no. 3, pp. 278-289, 2001.

[52] G. K. Ehrlich and P. Bailon, "Identification of model peptides as affinity ligands for the purification of humanized monoclonal antibodies by means of phage display," Journal of Biochemical and Biophysical Methods, vol. 49, no. 1-3, pp. 443-454, 2001.

[53] T. S. Romig, C. Bell, and D. W. Drolet, "Aptamer affinity chromatography: combinatorial chemistry applied to protein purification," Journal of Chromatography B, vol. 731, no. 2, pp. 275-284, 1999.

[54] J. E. Rasmussen, C. B. Schiødt, S. F. Christensen et al., "Smallmolecule affinity ligands for protein purification: combined computational enrichment and automated in-line screening of an optically encoded library," Angewandte Chemie, vol. 49, no. 20, pp. 3477-3480, 2010.

[55] N. Tugcu, M. Song, C. M. Breneman, N. Sukumar, K. P. Bennett, and S. M. Cramer, "Prediction of the effect of mobile-phase salt type on protein retention and selectivity in anion exchange systems," Analytical Chemistry, vol. 75, no. 14, pp. 3563-3572, 2003.

[56] Z. Xu, J. Li, and J. X. Zhou, "Process development for robust removal of aggregates using cation exchange chromatography in monoclonal antibody purification with implementation of quality by design," Preparative Biochemistry and Biotechnology, vol. 42, no. 2, pp. 183-202, 2012. 
[57] Y. Yigzaw, P. Hinckley, A. Hewig, and G. Vedantham, "Ion exchange chromatography of proteins and clearance of aggregates," Current Pharmaceutical Biotechnology, vol. 10, no. 4, pp. 421-426, 2009.

[58] T. Arakawa, K. Tsumoto, K. Nagase, and D. Ejima, "The effects of arginine on protein binding and elution in hydrophobic interaction and ion-exchange chromatography," Protein Expression and Purification, vol. 54, no. 1, pp. 110-116, 2007.

[59] Y. Yang, H. R. Hebron, and J. Hang, "High performance DNA purification using a novel ion exchange matrix," Journal of Biomolecular Techniques, vol. 19, no. 3, pp. 205-210, 2008.

[60] K. A. Barnthouse, W. Trompeter, R. Jones, P. I. Prasad Inampudi, R. Rupp, and S. M. Cramer, "Cation-exchange displacement chromatography for the purification of recombinant protein therapeutics from variants," Journal of Biotechnology, vol. 66, no. 2-3, pp. 125-136, 1998.

[61] C. J. Morrison and S. M. Cramer, "Characterization and design of chemically selective cationic displacers using a robotic highthroughput screen," Biotechnology Progress, vol. 25, no. 3, pp. 825-833, 2009.

[62] J. A. Gerstner, "Cation-exchange displacement chromatography of proteins with protamine displacers: effect of induced salt gradients," Biotechnology Progress, vol. 8, no. 6, pp. 540-545, 1992.

[63] S. D. Gadam, G. Jayaraman, and S. M. Cramer, "Characterization of non-linear adsorption properties of dextran-based polyelectrolyte displacers in ion-exchange systems," Journal of Chromatography A, vol. 630, no. 1-2, pp. 37-52, 1993.

[64] A. Kundu, S. Vunnum, G. Jayaraman, and S. M. Cramer, "Protected amino acids as novel low-molecular-weight displacers in cation-exchange displacement chromatography," Biotechnology and Bioengineering, vol. 48, no. 5, pp. 452-460, 1995.

[65] A. Kundu, S. Vunnum, and S. M. Cramer, "Antibiotics as low-molecular-mass displacers in ion-exchange displacement chromatography," Journal of Chromatography A, vol. 707, no. 1, pp. 57-67, 1995.

[66] G. Jayaraman, Y.-F. Li, J. A. Moore, and S. M. Cramer, "Ionexchange displacement chromatography of proteins. dendritic polymers as novel displacers," Journal of Chromatography A, vol. 702, no. 1-2, pp. 143-155, 1995.

[67] M.-K. Chern, W.-J. Shiah, J.-J. Chen, T.-Y. Tsai, H.-Y. Lin, and C.-W. Liu, "Single-step protein purification by back flush in ion exchange chromatography," Analytical Biochemistry, vol. 392, no. 2, pp. 174-176, 2009.

[68] M. E. Lienqueo, A. Mahn, L. Vásquez, and J. A. Asenjo, "Methodology for predicting the separation of proteins by hydrophobic interaction chromatography and its application to a cell extract," Journal of Chromatography A, vol. 1009, no. 1-2, pp. 189-196, 2003.

[69] A. Mahn, M. E. Lienqueo, and J. C. Salgado, "Methods of calculating protein hydrophobicity and their application in developing correlations to predict hydrophobic interaction chromatography retention," Journal of Chromatography A, vol. 1216, no. 10, pp. 1838-1844, 2009.

[70] P. Gagnon and E. Grund, "Large-scale process development for hydrophobic interaction chromatography, Part 4: controlling selectivity," BioPharm, vol. 9, no. 5, pp. 54-64, 1996.

[71] K. Tsumoto, D. Ejima, K. Nagase, and T. Arakawa, "Arginine improves protein elution in hydrophobic interaction chromatography. the cases of human interleukin-6 and activin-A," Journal of Chromatography A, vol. 1154, no. 1-2, pp. 81-86, 2007.
[72] Y. Kong, X. Li, G. Bai, G. Ma, and Z. Su, "An automatic system for multidimensional integrated protein chromatography," Journal of Chromatography A, vol. 1217, no. 44, pp. 6898-6904, 2010.

[73] T. Arakawa, Y. Kita, H. Sato, and D. Ejima, "MEP chromatography of antibody and Fc-fusion protein using aqueous arginine solution," Protein Expression and Purification, vol. 63, no. 2, pp. 158-163, 2009.

[74] G. Zhao, X.-Y. Dong, and Y. Sun, "Ligands for mixed-mode protein chromatography: principles, characteristics and design," Journal of Biotechnology, vol. 144, no. 1, pp. 3-11, 2009.

[75] T. Arakawa, Y. Kita, D. Ejima, and P. Gagnon, "Solvent modulation of column chromatography," Protein and Peptide Letters, vol. 15, no. 6, pp. 544-555, 2008.

[76] L. J. Cummings, M. A. Snyder, and K. Brisack, "Chapter 24 protein chromatography on hydroxyapatite columns," Methods in Enzymology, vol. 463, pp. 387-404, 2009.

[77] P. Gagnon, P. Ng, J. Zhen et al., "A ceramic hydroxyapatite based purification platform: simultaneous removal of leached protein A, aggregates, DNA, and endotoxins," BioProcess International, vol. 4, no. 2, pp. 50-60, 2006.

[78] M. Saito, Y. Kurosawa, and T. Okuyama, "Purification of antiJapanese encephalitis virus monoclonal antibody by ceramic hydroxyapatite chromatography without proteins A and G," Hybridoma, vol. 31, no. 1, pp. 68-71, 2012.

[79] D. Gao, S.-J. Yao, and D.-Q. Lin, "Preparation and adsorption behavior of a cellulose-based, mixed-mode adsorbent with a benzylamine ligand for expanded bed applications," Journal of Applied Polymer Science, vol. 107, no. 1, pp. 674-682, 2008.

[80] D. Gao, L. L. Wang, D.-Q. Lin, and S.-J. Yao, "Evaluating antibody monomer separation from associated aggregates using mixed-mode chromatography," Journal of Chromatography A, vol. 1294, pp. 70-75, 2013.

[81] J. Chen, J. Tetrault, Y. Zhang et al., "The distinctive separation attributes of mixed-mode resins and their application in monoclonal antibody downstream purification process," Journal of Chromatography A, vol. 1217, no. 2, pp. 216-224, 2010.

[82] F. E. Regnier, "High-performance liquid chromatography of biopolymers," Science, vol. 222, no. 4621, pp. 245-252, 1983.

[83] K. Štulík, V. Pacáková, and M. Tichá, "Some potentialities and drawbacks of contemporary size-exclusion chromatography," Journal of Biochemical and Biophysical Methods, vol. 56, no. 1-3, pp. 1-13, 2003.

[84] G. W. Welling, G. Groen, K. Slopsema, and S. WellingWester, "Combined size-exclusion and reversed-phase highperformance liquid chromatography of a detergent extract of Sendai virus," Journal of Chromatography A, vol. 326, pp. 173178, 1985.

[85] D. Ejima, R. Yumioka, T. Arakawa, and K. Tsumoto, "Arginine as an effective additive in gel permeation chromatography," Journal of Chromatography A, vol. 1094, no. 1-2, pp. 49-55, 2005.

[86] J. A. Asenjo and B. A. Andrews, "Protein purification using chromatography: selection of type, modelling and optimization of operating conditions," Journal of Molecular Recognition, vol. 22 , no. 2, pp. 65-76, 2009.

[87] J. Pollock, G. Bolton, J. Coffman, S. V. Ho, D. G. Bracewell, and S. S. Farid, "Optimising the design and operation of semicontinuous affinity chromatography for clinical and commercial manufacture," Journal of Chromatography A, vol. 1284, pp. 17-27, 2013. 
[88] E. Mahajan, A. George, and B. Wolk, "Improving affinity chromatography resin efficiency using semi-continuous chromatography," Journal of Chromatography A, vol. 1227, pp. 154$162,2012$.

[89] L. Aumann and M. Morbidelli, "A semicontinuous 3-column countercurrent solvent gradient purification (MCSGP) process," Biotechnology and Bioengineering, vol. 99, no. 3, pp. 728733, 2008.

[90] L. Aumann and M. Morbidelli, "A continuous multicolumn countercurrent solvent gradient purification (MCSGP) process," Biotechnology and Bioengineering, vol. 98, no. 5, pp. 10431055, 2007.

[91] T. Müller-Späth, L. Aumann, L. Melter, G. Ströhlein, and M. Morbidelli, "Chromatographic separation of three monoclonal antibody variants using multicolumn countercurrent solvent gradient purification (MCSGP)," Biotechnology and Bioengineering, vol. 100, no. 6, pp. 1166-1177, 2008.

[92] T. Müller-Späth, M. Krättli, L. Aumann, G. Ströhlein, and M. Morbidelli, "Increasing the activity of monoclonal antibody therapeutics by continuous chromatography (MCSGP)," Biotechnology and Bioengineering, vol. 107, no. 4, pp. 652-662, 2010.

[93] T. Müller-Späth, L. Aumann, G. Ströhlein et al., "Two step capture and purification of IgG2 using multicolumn countercurrent solvent gradient purification (MCSGP)," Biotechnology and Bioengineering, vol. 107, no. 6, pp. 974-984, 2010.

[94] A. Rajendran, G. Paredes, and M. Mazzotti, "Simulated moving bed chromatography for the separation of enantiomers," Journal of Chromatography A, vol. 1216, no. 4, pp. 709-738, 2009.

[95] L. Gueorguieva, S. Palani, U. Rinas, G. Jayaraman, and A. Seidel-Morgenstern, "Recombinant protein purification using gradient assisted simulated moving bed hydrophobic interaction chromatography. part II: process design and experimental validation," Journal of Chromatography A, vol. 1218, no. 37, pp. 6402-6411, 2011.

[96] T. Müller-Späth, G. Ströhlein, L. Aumann et al., "Model simulation and experimental verification of a cation-exchange IgG capture step in batch and continuous chromatography," Journal of Chromatography A, vol. 1218, no. 31, pp. 5195-5204, 2011.

[97] I. Sutherland, P. Hewitson, and S. Ignatova, "Scale-up of counter-current chromatography: demonstration of predictable isocratic and quasi-continuous operating modes from the test tube to pilot/process scale," Journal of Chromatography A, vol. 1216, no. 50, pp. 8787-8792, 2009.

[98] T. Seifert, S. Sievers, C. Bramsiepe, and G. Schembecker, "Small scale, modular and continuous: a new approach in plant design," Chemical Engineering and Processing, vol. 52, pp. 140-150, 2012.

[99] I. Šafarík and M. Šafaríková, "Overview of magnetic separations used in biochemical and biotechnological applications," in Scientific and Clinical Applications of Magnetic Carriers, U. Häfeli, W. Schütt, J. Teller, and M. Zborowski, Eds., pp. 323-340, Springer, New York, NY, USA, 1997.

[100] G. Li, R. Stewart, B. Conlan, A. Gilbert, P. Roeth, and H. Nair, "Purification of human immunoglobulin G: a new approach to plasma fractionation," Vox Sanguinis, vol. 83, no. 4, pp. 332-338, 2002.

[101] H. Kobayashi, K. Shimamura, T. Akaida et al., "Free-flow electrophoresis in a microfabricated chamber with a micromodule fraction separator-continuous separation of proteins," Journal of Chromatography A, vol. 990, no. 1-2, pp. 169-178, 2003.

[102] D. Catzel, H. Lalevski, C. P. Marquis, P. P. Gray, D. Van Dyk, and S. M. Mahler, "Purification of recombinant human growth hormone from $\mathrm{CHO}$ cell culture supernatant by Gradiflow preparative electrophoresis technology," Protein Expression and Purification, vol. 32, no. 1, pp. 126-134, 2003.

[103] C. C. Möller, D. Thomas, D. Van Dyk, D. Rylatt, and M. Sheehan, "Preparative-scale fractionation by isoelectric trapping under nondenaturing conditions: separation of egg white protein isoforms on a modified Gradiflow unit," Electrophoresis, vol. 26, no. 1, pp. 35-46, 2005.

[104] V. E. Klyushnichenko, R. V. Tikhonov, S. E. Pechenov et al., "Methods of preparation of recombinant Cytokine proteins: III. free-flow electrophoresis and chromatography in the production of mutant human recombinant tumor necrosis factor- $\alpha$," Protein Expression and Purification, vol. 14, no. 2, pp. 261-266, 1998.

[105] B. V. Bhut, K. A. Christensen, and S. M. Husson, "Membrane chromatography: protein purification from E. coli lysate using newly designed and commercial anion-exchange stationary phases," Journal of Chromatography A, vol. 1217, no. 30, pp. 4946-4957, 2010.

[106] C. Boi, S. Dimartino, S. Hofer et al., "Influence of different spacer arms on Mimetic Ligand A2P and B14 membranes for human IgG purification," Journal of Chromatography B, vol. 879, no. 19, pp. 1633-1640, 2011.

[107] V. Orr, J. Scharer, M. Moo-Young et al., "Simultaneous clarification of Escherichia coli culture and purification of extracellularly produced penicillin $G$ acylase using tangential flow filtration and anion-exchange membrane chromatography (TFFAEMC)," Journal of Chromatography B, vol. 900, pp. 71-78, 2012.

[108] R. T. Kurnik, A. W. Yu, G. S. Blank et al., "Buffer exchange using size exclusion chromatography, countercurrent dialysis, and tangential flow filtration: models, development, and industrial application," Biotechnology and Bioengineering, vol. 45, no. 2, pp. 149-157, 1995.

[109] A. Mehta and A. L. Zydney, "Effect of membrane charge on flow and protein transport during ultrafiltration," Biotechnology Progress, vol. 22, no. 2, pp. 484-492, 2006.

[110] R. Van Reis and A. L. Zydney, "Protein ultrafiltration," in Encyclopedia of Bioprocess Technology: Fermentation, Biocatalysis, and Bioseparation, M. C. Flickinger and S. W. Drew, Eds., pp. 2197-2214, John Wiley \& Sons, New York, NY, USA, 1999.

[111] Z. Cui, "Protein separation using ultrafiltration: an example of multi-scale complex systems," China Particuology, vol. 3, no. 6, pp. 343-348, 2005.

[112] M. T. Aspelund and C. E. Glatz, "Purification of recombinant plant-made proteins from corn extracts by ultrafiltration," Journal of Membrane Science, vol. 353, no. 1-2, pp. 103-110, 2010.

[113] R. Ghosh, S. S. Silva, and Z. Cui, "Lysozyme separation by hollow-fibre ultrafiltration," Biochemical Engineering Journal, vol. 6, no. 1, pp. 19-24, 2000.

[114] M. Mayani, C. D. M. Filipe, and R. Ghosh, "Cascade ultrafiltration systems-integrated processes for purification and concentration of lysozyme," Journal of Membrane Science, vol. 347, no. 1-2, pp. 150-158, 2010.

[115] M. Nystrom, N. Ehsani, and H. Ojamo, "Separation of lignocellulosics hydrolyzing enzymes with modified ultrafiltration membranes," Bioseparation, vol. 2, pp. 187-196, 1991.

[116] N. Ehsani and M. Nystrom, "Fractionation of BSA and myoglobin with modified and unmodified ultrafiltration membranes," Bioseparation, vol. 5, no. 1, pp. 1-10, 1995.

[117] N. Mameri, S. M. Oussedik, A. Khelifa, D. Belhocine, H. Ghrib, and H. Lounici, "Electric fields applied in the ultrafiltration process," Desalination, vol. 138, no. 1-3, p. 291, 2001. 
[118] M. Sung, C. P. Huang, Y.-H. Weng, Y.-T. Lin, and K.-C. Li, "Enhancing the separation of nano-sized particles in lowsalt suspensions by electrically assisted cross-flow filtration," Separation and Purification Technology, vol. 54, no. 2, pp. 170$177,2007$.

[119] C. C. Tarazaga, M. E. Campderrós, and A. P. Padilla, "Physical cleaning by means of electric field in the ultrafiltration of a biological solution," Journal of Membrane Science, vol. 278, no. 1-2, pp. 219-224, 2006.

[120] A. L. Ahmad and N. Ibrahim, "Automated electrophoretic membrane cleaning for dead-end microfiltration and ultrafiltration," Separation and Purification Technology, vol. 29, no. 2, pp. 105-112, 2002.

[121] K. S. Suslick, "Sonochemistry," Science, vol. 247, pp. 1439-1445, 1990.

[122] K. S. Suslick, Ultrasound: Its Chemical, Physical, and Biological Effects, VCH, New York, NY, USA, 1988.

[123] R. J. Wakeman and E. Tarleton, "Modelling, simulation and process design of the filter cycle," Filtration and Separation, vol. 27, no. 6, pp. $412-419,1990$.

[124] R. J. Wakeman and C. J. Williams, "Additional techniques to improve microfiltration," Separation and Purification Technology, vol. 26, no. 1, pp. 3-18, 2002.

[125] B. Sarkar, S. DasGupta, and S. De, "Electric field enhanced fractionation of protein mixture using ultrafiltration," Journal of Membrane Science, vol. 341, no. 1-2, pp. 11-20, 2009.

[126] C. Roblet, A. Doyen, J. Amiot, and L. Bazinet, "Impact of $\mathrm{pH}$ on ultrafiltration membrane selectivity during electrodialysis with ultrafiltration membrane (EDUF) purification of soy peptides from a complex matrix," Journal of Membrane Science, vol. 435, pp. 207-217, 2013.

[127] C. Christy, G. Adams, R. Kuriyel, G. Bolton, and A. Seilly, "High-performance tangential flow filtration: a highly selective membrane separation process," Desalination, vol. 144, no. 1-3, pp. 133-136, 2002.

[128] A. Saxena, B. P. Tripathi, M. Kumar, and V. K. Shahi, "Membrane-based techniques for the separation and purification of proteins: an overview," Advances in Colloid and Interface Science, vol. 145, no. 1-2, pp. 1-22, 2009.

[129] R. van Reis, S. Gadam, L. N. Frautschy et al., "High performance tangential flow filtration," Biotechnology and Bioengineering, vol. 56, no. 1, pp. 71-82, 1997.

[130] R. H. C. M. Van Eijndhoven, S. Saksena, and A. L. Zydney, "Protein fractionation using electrostatic interactions in membrane filtration," Biotechnology and Bioengineering, vol. 48, no. 4, pp. 406-414, 1995.

[131] S. M. Yoo and R. Ghosh, "Simultaneous removal of leached protein-A and aggregates from monoclonal antibody using hydrophobic interaction membrane chromatography," Journal of Membrane Science, vol. 390-391, pp. 263-269, 2012.

[132] H. N. Endres, J. A. C. Johnson, C. A. Ross, J. K. Welp, and M. R. Etzel, "Evaluation of an ion-exchange membrane for the purification of plasmid DNA," Biotechnology and Applied Biochemistry, vol. 37, no. 3, pp. 259-266, 2003.

[133] M. A. Teeters, S. E. Conrardy, B. L. Thomas, T. W. Root, and E. N. Lightfoot, "Adsorptive membrane chromatography for purification of plasmid DNA," Journal of Chromatography A, vol. 989, no. 1, pp. 165-173, 2003.

[134] T. M. Przybycien, N. S. Pujar, and L. M. Steele, "Alternative bioseparation operations: life beyond packed-bed chromatography," Current Opinion in Biotechnology, vol. 15, no. 5, pp. 469478, 2004.
[135] P. Å. Albertsson, Partition of Cell Particles and Macromolecules: Distribution and Fractionation of Cells, Viruses, Microsomes, Proteins, Nucleic Acids, and Antigen-Antibody Complexes in Aqueous Polymer Two-Phase Systems, John Wiley \& Sons, New York, NY, USA, 1960.

[136] A. M. Azevedo, L. P. Fonseca, and D. M. F. Prazeres, "Stability and stabilisation of penicillin acylase," Journal of Chemical Technology \& Biotechnology, vol. 74, no. 11, pp. 1110-1116, 1999.

[137] A. M. Azevedo, L. P. Fonseca, and D. M. Prazeres, "Twophase affinity partitioning of animal cells: implications of multipoint interactions," in Methods for Affinity-Based Separations of Enzymes and Proteins, M. N. Gupta, Ed., pp. 163-180, Springer, Basel, Switzerland, 2002.

[138] D. T. Kamei, J. A. King, D. I. C. Wang, and D. Blankschtein, "Understanding viral partitioning in two-phase aqueous nonionic micellar systems: 2. effect of entrained micelle-poor domains," Biotechnology and Bioengineering, vol. 78, no. 2, pp. 203-216, 2002.

[139] C. Kepka, J. Rhodin, R. Lemmens, F. Tjerneld, and P.-E. Gustavsson, "Extraction of plasmid DNA from Escherichia coli cell lysate in a thermoseparating aqueous two-phase system," Journal of Chromatography A, vol. 1024, no. 1-2, pp. 95-104, 2004.

[140] M. Bensch, B. Selbach, and J. Hubbuch, "High throughput screening techniques in downstream processing: preparation, characterization and optimization of aqueous two-phase systems," Chemical Engineering Science, vol. 62, no. 7, pp. 2011-2021, 2007.

[141] R. A. Hart, J. R. Ogez, and S. E. Builder, "Use of multifactorial analysis to develop aqueous two-phase systems for isolation of non-native IGF-I," Bioseparation, vol. 5, no. 2, pp. 113-121, 1995.

[142] P. A. J. Rosa, A. M. Azevedo, and M. R. Aires-Barros, "Application of central composite design to the optimisation of aqueous two-phase extraction of human antibodies," Journal of Chromatography A, vol. 1141, no. 1, pp. 50-60, 2007.

[143] M. Li and T. L. Peeples, "Purification of hyperthermophilic archaeal amylolytic enzyme (MJA1) using thermoseparating aqueous two-phase systems," Journal of Chromatography B, vol. 807, no. 1, pp. 69-74, 2004.

[144] C. Kepka, E. Collet, J. Persson et al., "Pilot-scale extraction of an intracellular recombinant cutinase from $E$. coli cell homogenate using a thermoseparating aqueous two-phase system," Journal of Biotechnology, vol. 103, no. 2, pp. 165-181, 2003.

[145] S. M. Waziri, B. F. Abu-Sharkh, and S. A. Ali, "Protein partitioning in aqueous two-phase systems composed of a $\mathrm{pH}$ responsive copolymer and poly(ethylene glycol)," Biotechnology Progress, vol. 20, no. 2, pp. 526-532, 2004.

[146] A. Nilsson, M. Mannesse, M. R. Egmond, and F. Tjerneld, "Cutinase-peptide fusions in thermoseparating aqueous twophase systems: prediction of partitioning and enhanced tag efficiency by detergent addition," Journal of Chromatography A, vol. 946, no. 1-2, pp. 141-155, 2002.

[147] S. Fexby, A. Nilsson, G. Hambraeus, F. Tjerneld, and L. Bülow, "Partitioning and characterization of tyrosine-tagged green fluorescent proteins in aqueous two-phase systems," Biotechnology Progress, vol. 20, no. 3, pp. 793-798, 2004.

[148] A. M. Azevedo, P. A. J. Rosa, I. F. Ferreira, and M. R. AiresBarros, "Chromatography-free recovery of biopharmaceuticals through aqueous two-phase processing," Trends in Biotechnology, vol. 27, no. 4, pp. 240-247, 2009. 
[149] S. Jain, R. Singh, and M. N. Gupta, "Purification of recombinant green fluorescent protein by three-phase partitioning," Journal of Chromatography A, vol. 1035, no. 1, pp. 83-86, 2004.

[150] I. Roy, A. Sharma, and M. N. Gupta, "Three-phase partitioning for simultaneous renaturation and partial purification of Aspergillus niger xylanase," Biochimica et Biophysica Acta, vol. 1698, no. 1, pp. 107-110, 2004.

[151] B. J. A. Paule, R. Meyer, L. F. Moura-Costa et al., "Threephase partitioning as an efficient method for extraction/ concentration of immunoreactive excreted-secreted proteins of Corynebacterium pseudotuberculosis," Protein Expression and Purification, vol. 34, no. 2, pp. 311-316, 2004.

[152] Y. A. Duman and E. Kaya, "Three-Phase partitioning as a rapid and easy method for the purification and recovery of catalase from sweet potato tubers (Solanum tuberosum)," Applied Biochemistry and Biotechnology, vol. 170, no. 5, pp. 11191126, 2013.

[153] E. Huenupi, A. Gomez, B. A. Andrews, and J. A. Asenjo, "Optimization and design considerations of two-phase continuous protein separation," Journal of Chemical Technology and Biotechnology, vol. 74, no. 2, pp. 256-263, 1999.

[154] S. L. Mistry, J. A. Asenjo, and C. A. Zaror, "Mathematical modelling and simulation of aqueous two-phase continuous protein extraction," Bioseparation, vol. 3, no. 6, pp. 343-358, 1992.

[155] S. L. Mistry, A. Kaul, J. C. Merchuk, and J. A. Asenjo, "Mathematical modelling and computer simulation of aqueous twophase continuous protein extraction," Journal of Chromatography A, vol. 741, no. 2, pp. 151-163, 1996.

[156] H. S. Mohammadi and E. Omidinia, "Process integration for the recovery and purification of recombinant Pseudomonas fluorescens proline dehydrogenase using aqueous two-phase systems," Journal of Chromatography B, vol. 929, pp. 11-17, 2013.

[157] P. O. Magalhães, A. M. Lopes, P. G. Mazzola, C. Rangel-Yagui, T. C. V. Penna, and A. Pessoa Jr., "Methods of endotoxin removal from biological preparations: a review," Journal of Pharmacy and Pharmaceutical Sciences, vol. 10, no. 3, pp. 388-404, 2007.

[158] Green-Cross, "Purification of urokinase and its precursor," Japanese Patent, J. 61227782, 1986.

[159] Y. Kang and R. G. Luo, "Chromatographic removal of endotoxin from hemoglobin preparations: effects of solution conditions on endotoxin removal efficiency and protein recovery," Journal of Chromatography A, vol. 809, no. 1-2, pp. 13-20, 1998.

[160] M.-F. Lin, C. Williams, M. V. Murray, and P. A. Ropp, "Removal of lipopolysaccharides from protein-lipopolysaccharide complexes by nonflammable solvents," Journal of Chromatography $B$, vol. 816, no. 1-2, pp. 167-174, 2005.

[161] R. H. Chen, C.-J. Huang, B. S. Newton, G. Ritter, L. J. Old, and C. A. Batt, "Factors affecting endotoxin removal from recombinant therapeutic proteins by anion exchange chromatography," Protein Expression and Purification, vol. 64, no. 1, pp. 76-81, 2009.

[162] T. E. Karplus, R. J. Ulevitch, and C. B. Wilson, "A new method for reduction of endotoxin contamination from protein solutions," Journal of Immunological Methods, vol. 105, no. 2, pp. 211-220, 1987.

[163] F. B. Anspach and O. Hilbeck, "Removal of endotoxins by affinity sorbents," Journal of Chromatography A, vol. 711, no. 1, pp. 81-92, 1995.

[164] H. Matsumae, S. Minobe, K. Kindan, T. Watanabe, T. Sato, and T. Tosa, "Specific removal of endotoxin from protein solutions by immobilized histidine," Biotechnology and Applied Biochemistry, vol. 12, no. 2, pp. 129-140, 1990.
[165] M. Sakata, T. Kawai, K. Ohkuma, H. Ihara, and C. Hirayama, "Reduction of endotoxin contamination of various crude vaccine materials by gram-negative bacteria using aminated $\operatorname{poly}(\gamma$-methyl L-glutamate) spherical particles," Biological and Pharmaceutical Bulletin, vol. 16, no. 11, pp. 1065-1068, 1993.

[166] J. Li, Y. Zhang, Z. Ping, M. Li, and Q. Zhang, "Synthesis and endotoxin removal properties of a novel affinity sorbent with poly(1-vinylimidazole) as the ligand," Process Biochemistry, vol. 46, no. 7, pp. 1462-1468, 2011.

[167] U. Ritzén, J. Rotticci-Mulder, P. Strömberg, and S. R. Schmidt, "Endotoxin reduction in monoclonal antibody preparations using arginine," Journal of Chromatography B, vol. 856, no. 1-2, pp. 343-347, 2007.

[168] C.-L. Liu, D. T. Kamei, J. A. King, D. I. C. Wang, and D. Blankschtein, "Separation of proteins and viruses using twophase aqueous micellar systems," Journal of Chromatography B, vol. 711, no. 1-2, pp. 127-138, 1998.

[169] A. M. Lopes, P. O. Magalhães, P. G. Mazzola et al., "LPS removal from an E. coli fermentation broth using aqueous two-phase micellar system," Biotechnology Progress, vol. 26, no. 6, pp. 16441653, 2010.

[170] S. Liu, R. Tobias, S. McClure, G. Styba, Q. Shi, and G. Jackowski, "Removal of Endotoxin from recombinant protein preparations," Clinical Biochemistry, vol. 30, no. 6, pp. 455-463, 1997.

[171] M. Cotten, A. Baker, M. Saltik, E. Wagner, and M. Buschle, "Lipopolysaccharide is a frequent contaminant of plasmid DNA preparations and can be toxic to primary human cells in the presence of adenovirus," Gene Therapy, vol. 1, no. 4, pp. 239246, 1994.

[172] M. Farshid, R. E. Taffs, D. Scott, D. M. Asher, and K. Brorson, "The clearance of viruses and transmissible spongiform encephalopathy agents from biologicals," Current Opinion in Biotechnology, vol. 16, no. 5, pp. 561-567, 2005.

[173] T. Burnouf, M. L. Chou, L. H. Cheng et al., "Dengue virus inactivation by minipool TnBP/Triton X-45 treatment of plasma and cryoprecipitate," Vox Sanguinis, vol. 104, no. 1, pp. 1-6, 2013.

[174] K. Brorson, J. Brown, E. Hamilton, and K. E. Stein, "Identification of protein A media performance attributes that can be monitored as surrogates for retrovirus clearance during extended re-use," Journal of Chromatography A, vol. 989, no. 1, pp. 155-163, 2003.

[175] L. Norling, S. Lute, R. Emery et al., "Impact of multiple re-use of anion-exchange chromatography media on virus removal," Journal of Chromatography A, vol. 1069, no. 1, pp. 79-89, 2005.

[176] G. Bolton, M. Cabatingan, M. Rubino, S. Lute, K. Brorson, and M. Bailey, "Normal-flow virus filtration: detection and assessment of the endpoint in bioprocessing," Biotechnology and Applied Biochemistry, vol. 42, no. 2, pp. 133-142, 2005.

[177] R. Specht, B. Han, S. R. Wickramasinghe et al., "Densonucleosis virus purification by ion exchange membranes," Biotechnology and Bioengineering, vol. 88, no. 4, pp. 465-473, 2004. 

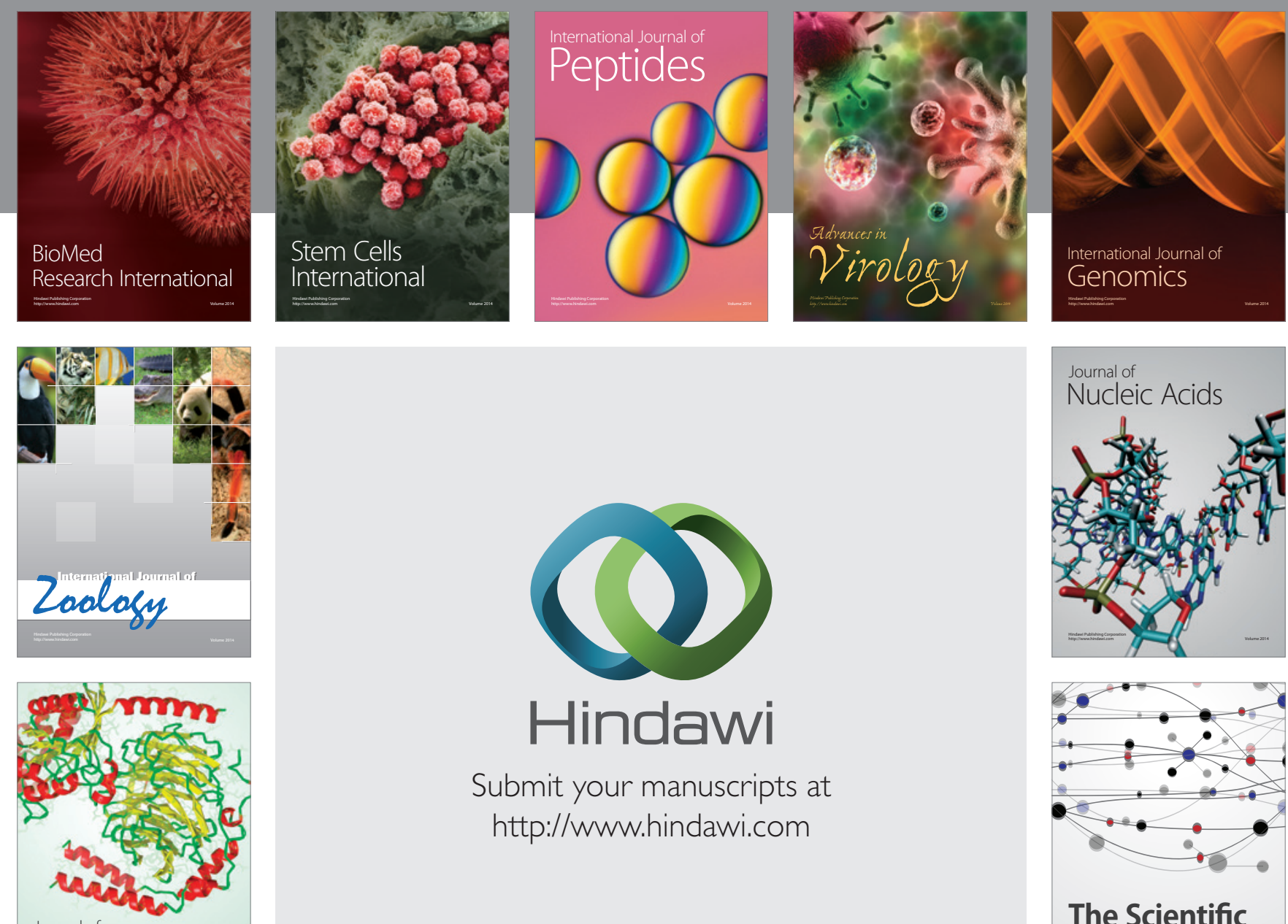

Submit your manuscripts at

http://www.hindawi.com

Journal of
Signal Transduction
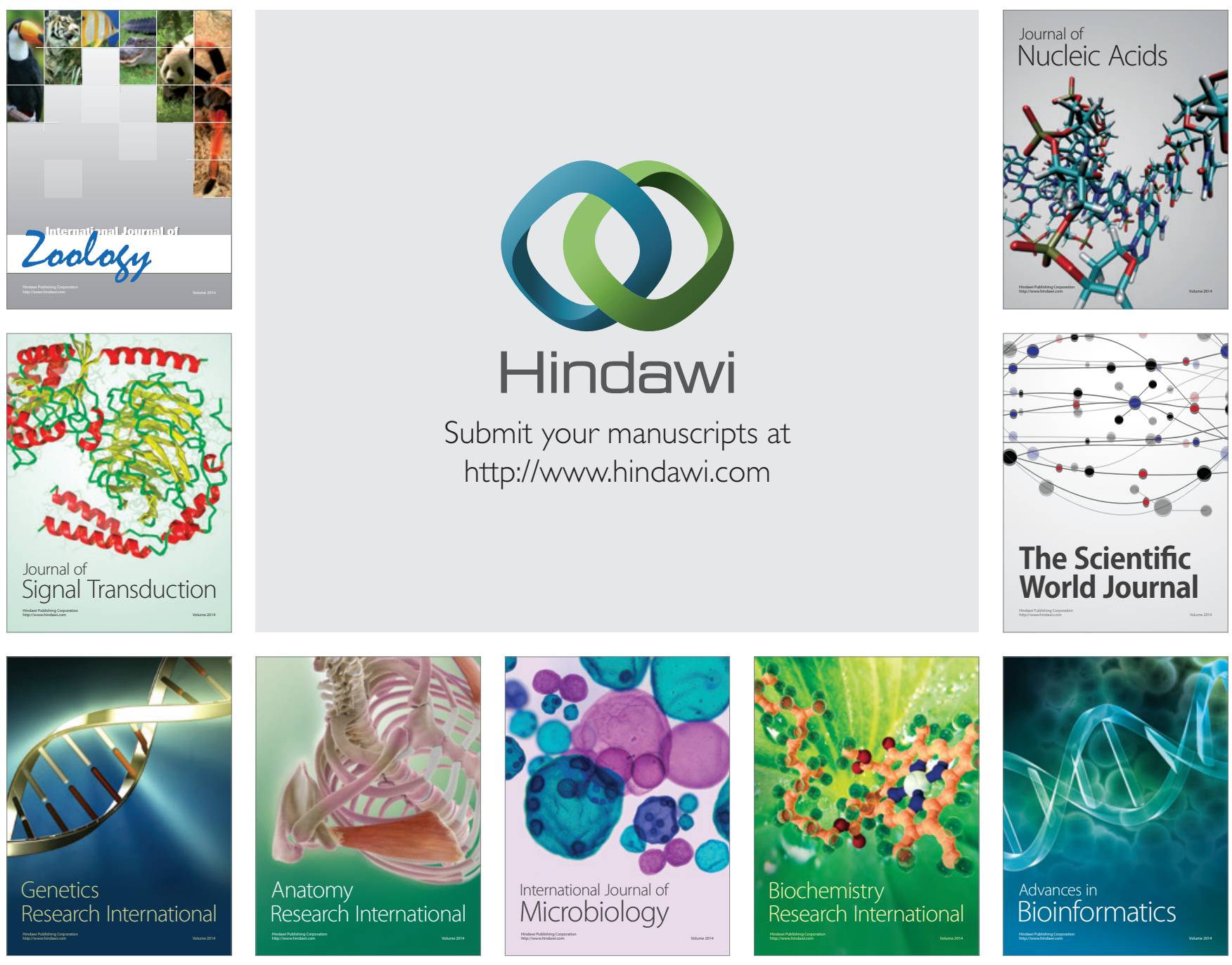

The Scientific World Journal
